\title{
Ethene, propene, butene and isoprene emissions from a ponderosa pine forest measured by relaxed eddy accumulation
}

\author{
Robert C. Rhew ${ }^{1}$, Malte Julian Deventer ${ }^{1, *}$, Andrew A. Turnipseed ${ }^{2, *}$, Carsten Warneke ${ }^{3,4}$, John Ortega ${ }^{5}$, \\ Steve Shen ${ }^{1}$, Luis Martinez ${ }^{6}$, Abigail Koss ${ }^{3,4}$, Brian M. Lerner ${ }^{3,4, a}$, Jessica B. Gilman ${ }^{3,4}$, James N. Smith ${ }^{5, b}$, \\ Alex B. Guenther ${ }^{7}$, and Joost A. de Gouw ${ }^{3}$ \\ ${ }^{1}$ Department of Geography and Berkeley Atmospheric Sciences Center, University of California Berkeley, \\ Berkeley, CA 94720-4740, USA \\ ${ }^{2}$ 2B Technologies, Boulder CO 80301, USA \\ ${ }^{3}$ Cooperative Institute for Research in Environmental Sciences (CIRES), University of Colorado Boulder, \\ Boulder CO 80309, USA \\ ${ }^{4}$ NOAA Earth System Research Laboratory, Boulder, CO 80305, USA \\ ${ }^{5}$ Atmospheric Chemistry Observations and Modeling (ACOM), National Center for Atmospheric Research, \\ Boulder, CO 80301, USA \\ ${ }^{6}$ Ernest F. Hollings Undergraduate Scholarship program, NOAA, Boulder, CO 80305, USA \\ ${ }^{7}$ Department of Earth System Science, University of California Irvine, Irvine, CA 92697-3100, USA \\ ${ }^{a}$ now at: Aerodyne Research Inc., Billerica, MA 01821-3976, USA \\ ${ }^{b}$ now at: Department of Chemistry, University of California Irvine, Irvine, CA 92697-2025, USA \\ ${ }^{*}$ These authors contributed equally to this work.
}

Correspondence to: Robert C. Rhew (rrhew@ berkeley.edu)

Received: 21 April 2017 - Discussion started: 4 May 2017

Revised: 9 September 2017 - Accepted: 28 September 2017 - Published: 10 November 2017

\begin{abstract}
Alkenes are reactive hydrocarbons that influence local and regional atmospheric chemistry by playing important roles in the photochemical production of tropospheric ozone and in the formation of secondary organic aerosols. The simplest alkene, ethene (ethylene), is a major plant hormone and ripening agent for agricultural commodities. The group of light alkenes $\left(\mathrm{C}_{2}-\mathrm{C}_{4}\right)$ originates from both biogenic and anthropogenic sources, but their biogenic sources are poorly characterized, with limited field-based flux observations. Here we report net ecosystem fluxes of light alkenes and isoprene from a semiarid ponderosa pine forest in the Rocky Mountains of Colorado, USA using the relaxed eddy accumulation (REA) technique during the summer of 2014. Ethene, propene, butene and isoprene emissions have strong diurnal cycles, with median daytime fluxes of $123,95,39$ and $17 \mu \mathrm{g} \mathrm{m}^{-2} \mathrm{~h}^{-1}$, respectively. The fluxes were correlated with each other, followed general ecosystem trends of $\mathrm{CO}_{2}$ and water vapor, and showed similar sunlight and temperature response curves as other biogenic VOCs. The May through Oc-
\end{abstract}

tober flux, based on measurements and modeling, averaged 62, 52, 24 and $18 \mu \mathrm{g} \mathrm{m}^{-2} \mathrm{~h}^{-1}$ for ethene, propene, butene and isoprene, respectively. The light alkenes contribute significantly to the overall biogenic source of reactive hydrocarbons: roughly $18 \%$ of the dominant biogenic VOC, $2-$ methyl-3-buten-2-ol. The measured ecosystem scale fluxes are $40-80 \%$ larger than estimates used for global emissions models for this type of ecosystem.

\section{Introduction}

In the troposphere, alkenes contribute to the photochemical production of tropospheric ozone. The "light alkenes", defined here as the $\mathrm{C}_{2}-\mathrm{C}_{4}$ alkenes, include $\mathrm{C}_{2} \mathrm{H}_{4}$ (ethene), $\mathrm{C}_{3} \mathrm{H}_{6}$ (propene) and $\mathrm{C}_{4} \mathrm{H}_{8}$ (1-butene, trans-2-butene, cis-2butene, and 2-methylpropene). Alkenes are especially important contributors to ozone production in the urban environment where they produce the most ozone per $\mathrm{C}$ atom oxi- 
dized; ethene and propene have the highest ozone production rates per carbon, followed by isoprene (Chameides et al., 1992; Seinfeld and Pandis, 1998). Like other NMHCs, these alkenes are initially oxidized by the hydroxyl radical $(\cdot \mathrm{OH})$, yielding intermediate peroxy radicals, which oxidize $\mathrm{NO}$ to $\mathrm{NO}_{2}$. Oxygen atoms released in the photodissociation of $\mathrm{NO}_{2}$ can react with $\mathrm{O}_{2}$ to form $\mathrm{O}_{3}$. Other reactions can yield organic nitrates that act as temporary reservoirs and transporters of $\mathrm{NO}_{x}$ (Poisson et al., 2000).

Light alkenes in the atmosphere originate from both anthropogenic and biogenic sources. Ethene, propene and butene are produced industrially by cracking petroleum hydrocarbons, and their double bond makes them versatile chemical feedstocks for industrial reactions. Ethene (also called ethylene) is the most abundant industrially produced organic compound, with global production capacity in 20092011 at 120 to $140 \mathrm{Tg} \mathrm{yr}^{-1}\left(\mathrm{Tg}=10^{12} \mathrm{~g}=\right.$ million metric tons) and US production at $\sim 23 \mathrm{Tg} \mathrm{yr}^{-1}$ (McCoy et al., 2010; UNEP, 2013). Propene (also known as propylene) is the raw material for polypropylene plastics and other products, and it is the second most abundant organic industrially produced compound, with production rates roughly half of ethene. Currently, global production of ethene and propene is estimated to amount to over $200 \mathrm{Tg}_{\mathrm{gear}}{ }^{-1}$, or about $30 \mathrm{~kg} \mathrm{person}^{-1}$ on Earth (Sholl and Lively, 2016). Anthropogenic emissions are only a fraction of that at 5.5 and $2.5 \mathrm{Tg} \mathrm{yr}^{-1}$ for ethene and propene, respectively, and mostly emanate from incomplete fuel combustion (Poisson et al., 2000). However, leakage of these compounds from industrial areas can impact regional atmospheric chemistry. For example, petrochemical ethene and propene were the primary nonmethane hydrocarbons (NMHCs) responsible for high ozone $\left(\mathrm{O}_{3}\right)$ concentrations near Houston during the 2000 TexAQS study (Wert et al., 2003; Ryerson et al., 2003; de Gouw et al., 2009).

Naturally produced alkenes are a significant portion of the overall carbon contribution of biogenic VOCs (BVOCs) to the atmosphere. Light alkene emissions are roughly $10 \%$ of isoprene (2-methyl-1,3-butadiene, $\mathrm{C}_{5} \mathrm{H}_{8}$ ), which is the dominant BVOC emitted globally (Poisson et al., 2000; Guenther et al., 2006). However, the spatial and temporal distributions of light alkene emissions are mostly unknown. While hundreds of studies have been conducted on isoprene emissions, including thousands of measurements on leaves, branches and whole plants (Guenther et al., 2006), global estimates

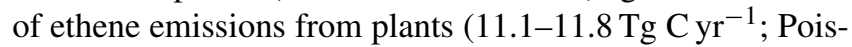
son et al., 2000; Singh and Zimmerman, 1992) are based largely on one laboratory study (Sawada and Totsuka, 1986), which incorporated 30 sets of incubations of plant shoots from five agricultural plants (wheat, cotton, bean, tomato and orange) and mesquite. These values were then extrapolated to all vegetation globally and scaled to biomass while omitting species effects, plant growth phase, stress, seasonality or diurnal trends in emissions.
Biogenic light alkene fluxes have been measured in only a few field studies. Large flux variability was observed in the net ecosystem fluxes of light alkenes at a temperate deciduous forest in Massachusetts (Harvard Forest) measured using a tower-based flux gradient method (Goldstein et al., 1996). Average emission rates at Harvard Forest were similar to the laboratory-based measurements reported by Sawada and Totsuka (1986), which is surprising given the very different measurement conditions and methods. Ethene, propene and 1butene emissions were observed from three tree species (willow, silver birch and aspen), although emission rates were only large for willow in the early season (Hakola et al., 1998). Other studies used flux chambers for surface-atmosphere exchange from low-lying vegetation; studies at a boreal wetland and forest floor in southwestern Finland (Hellén et al., 2006) and a rice field in Texas (Redeker et al., 2003) showed that those ecosystems are unlikely to be important sources of light alkenes. Elevated concentrations of alkenes were also observed in the ambient air of tropical forests in Brazil (Zimmerman et al., 1988) and in the upslope airflow in Hawaii (Greenberg et al., 1992), suggesting a local natural source for these compounds. The former was suggested to be largely from biomass burning and the latter from marine emissions, but the potential for biogenic terrestrial emissions was also noted.

The natural abiotic production of light alkenes can also occur through the photochemical processing of dissolved organic carbon in seawater (Ratte et al., 1998, 1993; Wilson et al., 1970). This process is believed to account for the majority of ethene production from rice fields, as evidenced from control experiment fluxes (Redeker et al., 2003). A separate abiotic production mechanism for ethene and propene has recently been reported from dry leaf litter, with emission rates increasing with temperature (Derendorp et al., 2011). However, these abiotic production rates were estimated to be insignificant in their global budgets.

The importance of alkenes in biochemistry is well recognized, especially for ethene. Ethene is essential in plant physiology and phenology, functioning as a plant hormone that regulates a myriad of plant processes, including seed germination, root initiation, root hair development, flower development, sex determination, fruit ripening, senescence and response to biotic and abiotic stresses (Yang and Hoffman, 1984; Reid and Wu, 1992; Lin et al., 2009). All plants and all plant parts produce ethene (typically called ethylene in the plant biology literature), a discovery first made in the 1930s from ripe apples (Gane, 1934). Consequently, ethene is widely used as a ripening agent for plants and plays an important role in the storage and preparation of agricultural commodities. As a plant hormone that responds to various stresses, the ethene source is likely to respond to land and climate modifications. Because of its agricultural importance, the biochemistry of ethene has been well studied by plant physiologists, while the biochemistry of the other light alkenes, such as propene and butene, remains unknown. 
Guenther et al. (2012) estimated the global biogenic volatile organic compound (BVOC) emissions for the year 2000 using the MEGAN (Model of Emissions of Gases and Aerosols from Nature) 2.1 algorithms in the land surface component, CLM4, of the Community Earth System Model (Guenther et al., 2012). In this study, they estimated that isoprene alone accounted for roughly half of the total annual BVOC emissions by mass at $\sim 535 \mathrm{Tg} \mathrm{yr}^{-1}$. The light alkenes, in contrast, only accounted for $5 \%$ of the total emissions. However, the algorithms for light alkene emissions are based on the very limited field and laboratory measurements described above, meaning that the potential for light alkenes may be much greater than this, especially for ecosystems with BVOC emissions that are not isoprene dominated.

The present study seeks to (a) describe the development and deployment of a continuous REA system to measure net ecosystem fluxes of light hydrocarbons at hourly intervals, (b) provide the first net ecosystem flux measurements of light alkenes from a ponderosa pine forest during the growing season, (c) place these results in the context of the $\mathrm{OH}$ reactivity of other BVOCs that were measured at the site previously and (d) develop emissions parameterizations based on environmental factors for entry into the MEGAN model.

\section{Site description}

In the summer of 2014, a field campaign was conducted at Manitou Experimental Forest Observatory (MEFO) in the Front Range of the central Rocky Mountains $\left(39.1^{\circ} \mathrm{N}\right.$, $105.1^{\circ} \mathrm{W}, 2280$ to $2840 \mathrm{~m}$ a.s.l.), located roughly $100 \mathrm{~km}$ south-southwest of Denver, Colorado, USA (Fig. 1). The forest is predominantly ponderosa pine with a median tree age of $\sim 50$ years and an average canopy height of $18.5 \mathrm{~m}$ (Ortega et al., 2014). Other local vegetation includes Douglas fir, aspen, mixed conifer and an understory of primarily grasses. Soils have low organic matter content (1-4\%) and good drainage (i.e., rapid permeability $\sim 50-150 \mathrm{~mm} \mathrm{~h}^{-1}$ ); soil depth to bedrock averages 1 to $1.8 \mathrm{~m}$ (Ortega et al., 2014).

The climate at MEFO can be described as cold-moderate and dry ( $430 \mathrm{~mm}$ average annual precipitation). Summers are characterized by low humidity and feature hot days (average highs between 22 and $26^{\circ} \mathrm{C}$ ) with frequent thunderstorms. Long-term observations indicate that about half of the annual precipitation falls during the summer (Ortega et al., 2014).

The Manitou Experimental Forest research site was initially established by the USDA Forest Service in 1936 (http: //www.fs.usda.gov/manitou/). In 2008, the National Center for Atmospheric Research (NCAR) established MEFO as part of the Bio-hydro-atmosphere interactions of Energy, Aerosols, Carbon, $\mathrm{H}_{2} \mathrm{O}$, Organics and Nitrogen (BEA$\mathrm{CHON}$ ) project. The infrastructure at the site includes a $28 \mathrm{~m}$ walk-up "chemistry tower"; mobile laboratory containers are located at the base, with line power and temperature control. As part of the BEACHON project, two major field inten-

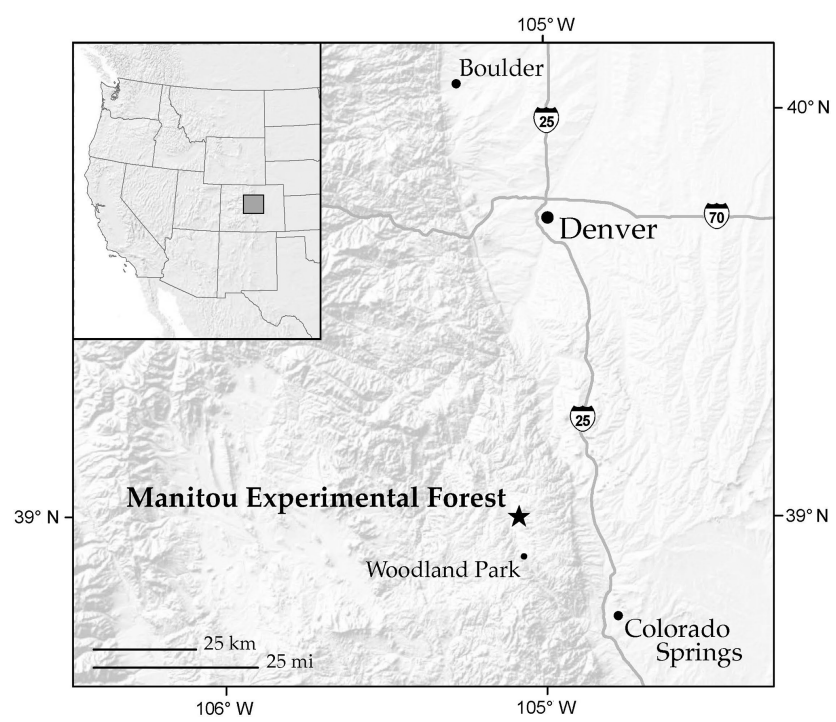

Figure 1. The Manitou Experimental Forest Observatory, located in the Front Range of the Rocky Mountains, is shown relative to the cities of Denver, Boulder, Colorado Springs and Woodland Park in Colorado. Interstate highways 25 and 70 are shown.

sives were conducted: BEACHON-ROCS (Rocky Mountain Organic Carbon Study) in 2010 and BEACHON-RoMBAS (Rocky Mountain Biogenic Aerosol Study) in 2011. Ortega et al. (2014) provide a detailed description of the site and an overview of the BEACHON projects between 2008 and 2013.

As a result of the BEACHON projects, meteorological and gas-phase measurements have been made on the chemistry tower for multiple consecutive growing seasons. Since 2009, these measurements have included wind speed and direction, temperature, humidity and pressure (2-D sonic anemometer, Vaisala WXT520), and photosynthetically active radiation (PAR) at four locations from the ground level to the top of the tower (Licor LI190SA and Apogee LQS sensors). Directand diffuse-beam PAR (Delta-T BF3) were also measured at the top of the tower $\sim 28 \mathrm{~m}$ above ground level (a.g.l.; Ortega et al., 2014).

The MEFO site is located in a gently sloping drainage valley, with air draining to the north. At nighttime the mountainto-valley flow prevails, with winds largely from south to north. During the daytime, southerly flow also occurs, but there is much more variability in wind direction (Ortega et al., 2014).

In this field campaign, net ecosystem fluxes of light alkenes were measured from 25 June to 9 August 2014 (day of year (DOY) 176-221), with a gap between 29 June at noon and 16 July at noon (DOY 180-197) owing to instrument problems. Understory fluxes were measured during a case study day on 2 September 2014 after relocating the equipment to a lower measurement height ( $2 \mathrm{~m}$ a.g.l.). The average temperature and precipitation totals during this 
field campaign were $15.9^{\circ} \mathrm{C}$ and $210 \mathrm{~mm}$, respectively. On a monthly scale, June 2014 was dry $\left(16.1^{\circ} \mathrm{C}, 8 \mathrm{~mm}\right)$, July was notably wet $\left(16.6^{\circ} \mathrm{C}, 151.3 \mathrm{~mm}\right)$ and August was consistent with long-term observations $\left(14^{\circ} \mathrm{C}, 74 \mathrm{~mm}\right)$. Several notable precipitation events occurred on 12 July (DOY 193, $25 \mathrm{~mm}$ ), 25 July (DOY 206, $14 \mathrm{~mm}$ ) and 30 July (DOY 211, $13 \mathrm{~mm}$ ). A longer-lasting precipitation event was recorded during 1517 July (DOY 196-198, $30 \mathrm{~mm}$ ), during which hail was also observed (e.g., 16 July, DOY 197).

Over the timescale of this field campaign, the air temperature exhibited three synoptic-scale weather fluctuations lasting about 2 weeks each. These slow fluctuations coincided with fluctuations in ambient pressure and can be explained by changes in local weather systems. On sunny days, net radiation reached $880 \mathrm{~W} \mathrm{~m}^{-2}$, yielding up to $2000 \mu \mathrm{mol} \mathrm{m}^{-2} \mathrm{~s}^{-1}$ of photosynthetically active radiation (PAR). The duration of daylight was almost $15 \mathrm{~h} \mathrm{day}^{-1}$. Hourly time is reported here as Mountain Standard Time (MST $=\mathrm{UTC}-7 \mathrm{~h}$ ).

\section{Methods}

To quantify the net ecosystem exchange of biogenic hydrocarbons, we employed a relaxed eddy accumulation (REA) sampling system coupled to an automated gas chromatography system with flame ionization detection (GC-FID). The REA sampling system was located near the top of the chemistry tower, while the gas measurement systems were located in the laboratory at the base of the tower. The following sections describe the REA theory, the REA instrumentation and setup, the automated GC-FID system and the additional measurement systems deployed during these experiments.

\subsection{Relaxed eddy accumulation (REA) theory}

Net ecosystem fluxes for a suite of hydrocarbons were measured on an hourly basis using the relaxed eddy accumulation (REA) method. REA is a micrometeorological flux measurement technique that permits in situ flux measurements for chemical species that cannot be measured at the high frequency required for eddy covariance techniques (Businger and Oncley, 1990). To date, no light alkene sensor meets the requirements for detection limit, accuracy, sensitivity and response time for eddy covariance measurements in natural ecosystems. REA systems have been successfully used for other biogenic volatile organic compounds, including isoprene (Bowling et al., 1998; Guenther et al., 1996; Haapanala et al., 2006) and OVOCs (Schade and Goldstein, 2001; Baker et al., 2001).

The REA technique is described in detail in Businger and Oncley (1990); therefore, only a brief description is provided here. Air samples are conditionally sampled into an updraft reservoir, a downdraft reservoir or a neutral bypass controlled by fast response valves that respond to high-frequency 3-D sonic anemometer measurements of the vertical wind veloc- ity $(w)$. Mean vertical wind velocity $(\bar{w})$ is determined for a flux averaging period, and the instantaneous vertical wind velocity is calculated $\left(w^{\prime}=w(t)-\bar{w}\right)$. The REA method is derived from the eddy accumulation method (Desjardins, 1977) but "relaxes" the requirement of sampling at flow rates proportional to the vertical wind speed. In both methods, a turbulent flux is derived from the differences between averaged concentrations in the updraft $\left(\overline{c^{+}}\right)$and downdraft $\left(\overline{c^{-}}\right)$reservoirs collected over some flux averaging period (typically 30-60 min). In the surface layer, the concentration differences are scaled by the standard deviation of $w\left(\sigma_{w}\right)$ and the dimensionless Businger-Oncley parameter $(b)$ to yield the vertical flux (Eq. 1):

$F=b \sigma_{w}\left(\overline{c^{+}}-\overline{c^{-}}\right)$.

In theoretical solutions, $b$ was found to be a weak function of atmospheric stability (Businger and Oncley, 1990). Wyngaard and Moeng (1992) simulate $b$ to be fairly constant $(b \sim 0.627)$ assuming a Gaussian joint probability density function between $w$ and $c$. Empirical approximations based on direct eddy covariance measurements show some variation in the $b$ coefficient on a diurnal basis, and although it varies for different scalars, estimates usually fall in the range of $0.51<b<0.62$ (Katul et al., 1996; Ruppert et al., 2006; Baker, 2000; Pattey et al., 1993; Baker et al., 1992). Consequently, a dynamic $b$ value is often used, calculated for each REA averaging interval based on concurrent eddy covariance (EC) measurements of a proxy scalar under the assumption of scalar similarity (Pattey et al., 1993). In this case, $c$ is replaced with the proxy scalar of temperature, measured by the sonic anemometer. The value of $b$ can be calculated from the sonic temperature and by rearranging Eq. (1) as follows (Eq. 2):

$b=\frac{\left(\overline{w^{\prime} T^{\prime}}\right)}{\sigma_{w}\left(\overline{T^{+}}-\overline{T^{-}}\right)}$,

where $\left(\overline{w^{\prime} T^{\prime}}\right)$ is the covariance between instantaneous fluctuations of $w$ and temperature, i.e., the heat flux, averaged over the chosen time interval and $\left(\overline{T^{+}}, \overline{T^{-}}\right)$values are the mean temperatures during updraft and downdraft sampling, respectively. Ruppert et al. (2006) investigated scalar similarity between water vapor, sonic temperature and carbon dioxide and found a diurnal pattern in scalar correlation coefficients leading to an error of $F_{\mathrm{REA}} \leq 10 \%$.

To increase the accuracy of conditional sampling and maximize the signal-to-noise ratio in $\Delta \bar{c}$, samples during very small $w^{\prime}$ are discarded via a neutral bypass as part of a "deadband" (Baker, 2000). For each flux averaging interval, a symmetrical threshold $\left(w_{0}\right)$ around the mean wind velocity is applied, whereby the updraft reservoir is sampled when $w^{\prime} \geq w_{0}$ and the downdraft is sampled when $w^{\prime} \leq-w_{0}$. Oncley et al. (1993) analytically solved the ratio between an 


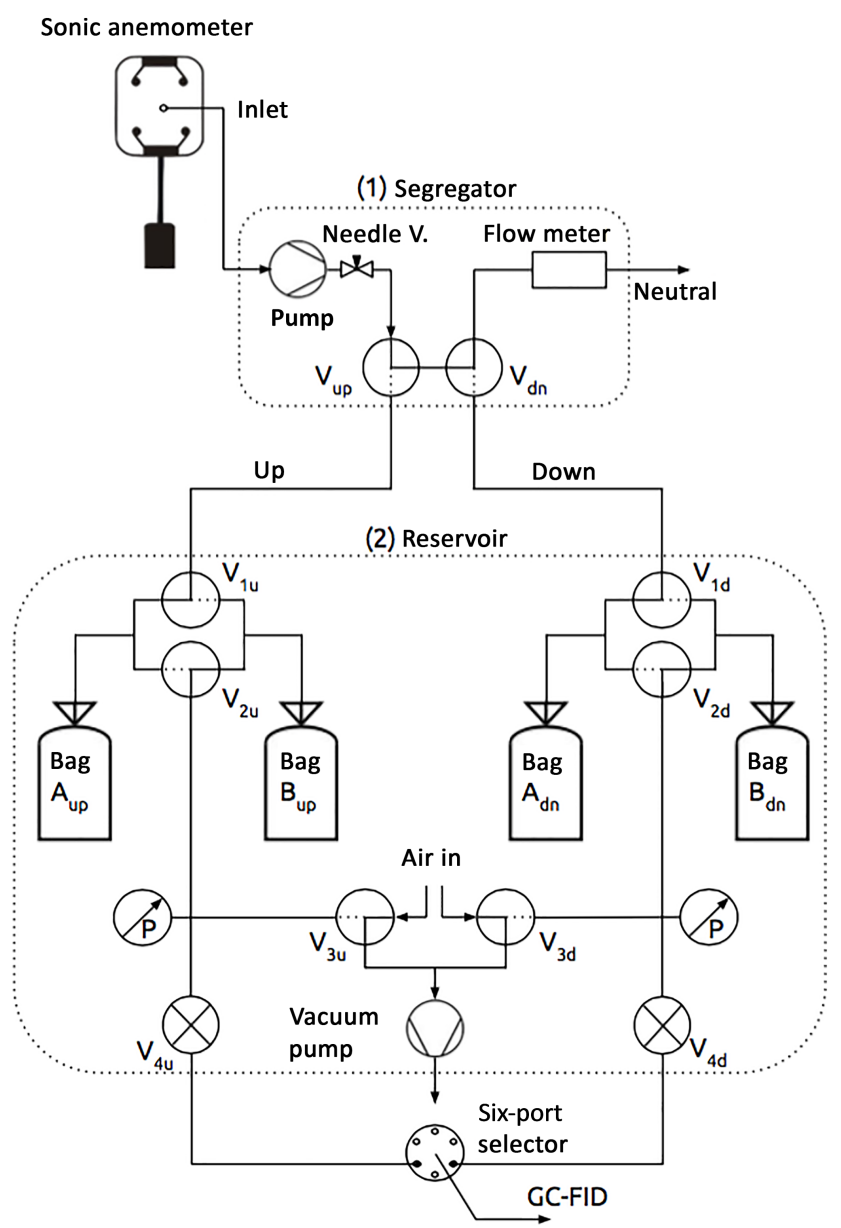

Figure 2. The relaxed eddy accumulation (REA) system is comprised of (1) a segregator subsystem and (2) a reservoir subsystem. Sample valves are indicated by V, with updraft (up) and downdraft (dn) air sampling valves and bag reservoirs shown.

increase in the uncertainty of $\bar{c}$ due to shorter sampling intervals with increasing $w_{0}$ and an improvement in the signalto-noise ratio; they report an optimum at $w_{0}=0.6 \sigma_{w}$, which was used in this study. For each flux averaging interval, the Businger-Oncley parameter is computed from Eq. (2) using the same deadband. The deadband-related increase in $\Delta \bar{T}$ consequently leads to smaller $b$ values that are $\sim 0.4$.

In REA measurements, both $\bar{w}$ and $\sigma_{w}$ need to be initialized in real time to determine what constitutes an updraft and downdraft within each flux averaging interval. Based on the analysis of Turnipseed et al. (2009), we chose to use $\bar{w}$ and $\sigma_{w}$ from the previous flux averaging interval.

\subsection{REA instrumentation}

The physical REA instrumentation consists of two subsystems: (1) an air sampling subsystem to segregate the sample flow into an up- and down-line (or neutral bypass line) according to the vertical wind velocity and (2) a reservoir sys- tem, for storage, transfer and evacuation of the sampled air (Fig. 2). The subsequent description follows the flow of air through the system.

1. The air sampling subsystem consisted of a sonic anemometer and segregator box, both mounted $25.1 \mathrm{~m}$ a.g.1. on the end of a $1.2 \mathrm{~m}$ boom (metal cross beam) extending outward from the top level of the walk-up chemistry tower. Vertical wind velocity was measured with an ultrasonic anemometer (model 81000; R. M. Young, Traverse City, MI, USA), which transmitted data at a $5 \mathrm{~Hz}$ frequency via RS-232 to a CR-1000 data logger (Campbell Scientific Inc., Logan, UT, USA). A $75 \mathrm{~cm}$ long $1 / 8^{\prime \prime}$ outer diameter by $1 / 16^{\prime \prime}$ inner diameter PTFE tube (EW-06605-27; Cole Parmer, Vernon Hills, IL, USA) was attached to the sonic anemometer (horizontal offset $\approx 0 \mathrm{~cm}$ and vertical offset $=10 \mathrm{~cm}$ with respect to the center of the anemometer's measurement path). Sample air was drawn into the segregator box (also mounted on the boom) via a micro-diaphragm pump (UNMP805; KNF Neuberger Inc., Trenton, NJ, USA), with airflow restricted by a stainless steel needle valve. The segregator split the airflow into an up-line, down-line and neutral line by two logger-controlled PTFE diaphragm solenoid valves $\left(\mathrm{V}_{\mathrm{up}}\right.$ and $\mathrm{V}_{\mathrm{dn}}$, Fig. 2; 100T3MP12-62M; BioChem Fluidics Inc., Boonton, NJ, USA). The neutral line was activated when vertical wind velocities fell into the deadband (see Sect. 3.1 above). Neutral airflow was directed through an airflow sensor (AWM3300V; Honeywell International Inc., Morris Plains, NJ, USA) and finally vented out of the segregator.

2. The reservoir subsystem was mounted on a platform $1 \mathrm{~m}$ below the sonic anemometer to collect updraft and downdraft air into two separate sample containers for temporary storage and subsequent analysis. After passing the segregator, sample air was directed either into an "up" bag or a "down" bag (10 L Tedlar ${ }^{\circledR}$ bag 23110; SKC Inc., Eighty Four, PA, USA) controlled by three-way lift solenoid valves $V_{1}$ and $V_{2}$ (Fig. 2). All valves of the reservoir system were identical and connected by $1 / 8^{\prime \prime}$ OD PTFE tubing (EW-01540-17 and EW-06605-27; Cole Parmer, Vernon Hills, IL, USA). There were two sets of up and down bags (set $A_{u p} / A_{d n}$ and set $B_{u p} / B_{d n}$ ), allowing one pair of bags to be analyzed while the other set was simultaneously used for sampling (60 min).

For the sample set being measured, air from each bag was transferred sequentially (18 min each) through solenoid valves $\mathrm{V}_{4 \mathrm{u}}$ or $\mathrm{V}_{4 \mathrm{~d}}$ (Fig. 2). Two sample lines $\left(1 / 4^{\prime \prime}\right.$ PTFE tubing wrapped in foam insulation) extended down to the laboratory trailer at the base of the tower, and air samples were drawn from the reservoir bags to the gas chromatograph (see next section). 
To address the potential issue of different storage time in the bags, the order of sample analysis alternated between each hourly flux sampling interval (e.g., 13:00: up bag, down bag; 14:00: down bag, up bag). After the transfer, airflow to the GC was shut off and the remaining air in the up or down reservoir bag was evacuated for $15 \mathrm{~min}$ through solenoid valve $\mathrm{V}_{3 \mathrm{u}}$ or $\mathrm{V}_{3 \mathrm{~d}}$ using a vacuum pump (UNMP805; KNF Neuberger Inc., Trenton, NJ, USA; Fig. 2), with less than $2 \%$ carryover from one sample to the next; additional details are described in the Supplement.

\subsection{REA processing and quality control}

Real-time measurements of vertical wind velocity (w) were collected on a data logger (CR1000; Campbell Scientific Inc., Logan, UT, USA), which also relayed the signal following the sampling lag time (see Supplement) to control the segregator sampling line valves, $\mathrm{V}_{\mathrm{up}}$ and $\mathrm{V}_{\mathrm{dn}}$, accordingly. The high-frequency time series of sonic temperature $(T)$ were stored in the data logger's memory for subsequent calculation of the covariance of $w$ and $\left.T: \overline{\left(w^{\prime} T^{\prime}\right.}\right)$. Sonic temperature was also conditionally averaged into $\overline{T^{+}}$and $\overline{T^{-}}$for calculation of the $b$ coefficient (Eq. 2). At the end of each flux averaging interval, $\bar{w}$ and $\sigma_{w}$ were calculated by the data logger and used to initialize the deadband for the following sampling hour and to compute the instantaneous fluctuations of vertical wind speeds $\left(w^{\prime}\right)$. In addition, the logger also triggered the bag selection valves $\left(\mathrm{V}_{1}\right.$ and $\left.\mathrm{V}_{2}\right)$ when switching to the other pair of updraft and downdraft reservoirs (set A vs. set B bags; Fig. 2). For quality control, the volume of sampled air in each bag, the volume of expelled neutral air and the average sampling flow rate were saved on the data logger's memory. Quality control for each hourly REA flux measurement was checked against eight potential flags associated with the sample volumes, meteorological conditions or footprint analysis (Fig. S1, Supplement).

Flux detection limits $\left(F_{\min }\right)$ were calculated by using Eq. (3):

$F_{\min }=b \sigma_{w} 2 \sigma_{c_{-} \mathrm{SD}}$

where $2 \sigma_{c_{-} S \mathrm{SD}}$ is the analytical precision based on 2 standard deviations of hourly repeated GC-FID runs of the calibration standard (see Sect. 3.6 below). The lowest flux detection limit (LDL) was determined for isoprene $\left(F_{\min }=\right.$ $\left.3.4 \mu \mathrm{g} \mathrm{m}^{-2} \mathrm{~h}^{-1}\right)$, followed by ethene and butene $\left(F_{\min }=\right.$ $\left.4.1 \mu \mathrm{g} \mathrm{m}^{-2} \mathrm{~h}^{-1}\right)$ and propene $\left(F_{\min }=4.7 \mu \mathrm{g} \mathrm{m}^{-2} \mathrm{~h}^{-1}\right)$. Flux observations that were negative or below $F_{\min }$ were included in the overall statistical analyses (median and percentiles, means and standard deviations) but excluded for the curve fitting in response to temperature and PAR. The number of fluxes $<$ LDL varied as follows: ethene $(n=12)$, propene $(n=33)$, butene $(n=93)$, isoprene $(n=105)$, acetylene $(n=380)$ and benzene $(n=158)$.

\subsection{Understory REA fluxes}

Understory flux measurements were performed on a single day, 2 September 2014 (about 1 month after the main experiment), to provide insight on the magnitude of fluxes that may be emanating from the surface instead of the tree canopy. These understory fluxes were measured by mounting the REA sampling system to a separate smaller scaffold, with the inlet line and sonic anemometer placed at $2 \mathrm{~m}$ a.g.l. Hourly fluxes were measured starting at 06:00 and ending at 17:00, with the up and down bag samples being transferred to electropolished stainless steel canisters for later analysis in the laboratory on the same gas chromatograph used during the field season.

The challenge with understory measurements is that they are prone to sampling artifacts due to flow distortion and low wind speeds. Furthermore, turbulence tends to be intermittent, and there is a lack of universal theories on sub-canopy turbulence characteristics, i.e., (co)spectral models (Launiainen et al., 2005).

In this study, the understory turbulence (defined here as the standard deviation of vertical wind) evolved over the course of the day from $0.04 \mathrm{~m} \mathrm{~s}^{-1}$ at night and in the early morning to over $0.1 \mathrm{~m} \mathrm{~s}^{-1}$ at 09:00 MST to a maximum of $\sim 0.4 \mathrm{~m} \mathrm{~s}^{-1}$ (Fig. S2). In previous sub-canopy flux studies, a $\sigma_{w}$ mixing criterion was empirically determined at $0.1 \mathrm{~m} \mathrm{~s}^{-1}$ (Launiainen et al., 2005). Thus, measured fluxes in periods with insufficient mixing (small $\sigma_{w}$ ) do not represent the real surface-atmosphere exchange. Our observations support the use of a similar criterion: sensible heat fluxes were highly variable under low turbulence conditions but showed weak dependence on $\sigma_{w}$ with increasing $\sigma_{w}$. A site-specific $\sigma_{w}$ threshold was determined at $0.4 \mathrm{~m} \mathrm{~s}^{-1}$.

\subsection{Gap filling model}

Flux measurement time series are often fragmented due to questionable turbulence statistics, unfavorable wind directions or sensor failure. Hence diurnally or seasonally averaged fluxes can be biased if time series are not gap filled. Gap filling the REA-derived fluxes was performed here using an artificial neural network (ANN) approach (Moffat et al., 2007; Papale et al., 2006). ANN is increasingly used in eddy covariance studies because of its ability to resolve nonlinear relationships and complex interactions between flux drivers (Dengel et al., 2013; Papale and Valentini, 2003). Input variables included air temperature, photosynthetically active radiation, water vapor flux and standard deviation of the vertical wind speed. Prior to gap filling, input variables were normalized on a scale of -1 (for minimum value) to +1 (for maximum value). Inputs variables $(n=1223$ each) were then divided into $k=20$ clusters via the $k$-means method, a cluster analysis tool that partitions $n$ observations into $k \leq n$ clusters by minimizing the inner-cluster variance. From those clusters, explanatory data were proportionally sampled into 
train, test and validation subsets. This procedure aims at avoiding a bias in network training towards data subsets with better data coverage. In total, 20 extractions out of these subsets were performed and run for 5 network architectures with increasing complexity. The best architecture for each of the 20 extractions was chosen according to the lowest root mean square error (through comparison with the validation subset, which is not used for training the networks) and the lowest complexity and then used to compute a predicted flux. Gap filling was finally performed using the median of the 20 resulting predictions.

Goodness of prediction was quantified by using coefficients of determination $\left(r^{2}\right)$ between median prediction and measured data, as well as by root mean square error (RMSE). For ethene $r^{2}=0.70$ and $\mathrm{RMSE}=32.1 \mu \mathrm{g} \mathrm{m}^{-2} \mathrm{~h}^{-1}$, for propene $r^{2}=0.71$ and RMSE $=27.7 \mu \mathrm{g} \mathrm{m}^{-2} \mathrm{~h}^{-1}$, for butene $r^{2}=0.80$ and $\mathrm{RMSE}=8.6 \mu \mathrm{g} \mathrm{m}^{-2} \mathrm{~h}^{-1}$ and for isoprene $r^{2}=0.3$ and RMSE $=38.9 \mu \mathrm{g} \mathrm{m}^{-2} \mathrm{~h}^{-1}$. The lower performance for isoprene was due to the difficulty in predicting intermittent large negative fluxes.

\subsection{GC-FID measurement}

Hydrocarbons $\left(\mathrm{C}_{2}-\mathrm{C}_{5}\right.$ alkenes including isoprene, $\mathrm{C}_{2}-\mathrm{C}_{6}$ alkanes, acetylene and some aromatics) were measured with a gas chromatograph with a flame ionization detector (GCFID; Fig. S3). The automated GC-FID was originally developed for aircraft operation, with 45 hydrocarbons resolved on the capillary column with a detection limit of 2 to $5 \mathrm{ppt}$ for a $350 \mathrm{~cm}^{3}$ STP sample (Goldan et al., 2000; Kuster et al., 2004). The system was modified here to optimize light hydrocarbon measurements using 20 min run times, and calibration standards were analyzed between sample runs to produce daily calibration curves, from which concentrations were derived (Supplement). This study focused on ethene, propene, isoprene, acetylene, benzene and the three butene isomers (trans-2-butene, 1-butene and cis-2-butene), which were all well resolved by the chromatography. However, the trio of butene isomers had retention times that were clustered together, and these were all present in equal amounts in the calibration standards. Only one of the butene isomers showed consistently significant signals in this study, and this compound was identified tentatively as cis-2-butene based on its retention time. This compound is reported in this study as "butene" to account for its molar mass and chemical makeup while allowing for the uncertainty of the specific isomer being measured (Supplement).

\subsection{Eddy covariance $\mathrm{H}_{2} \mathrm{O}$ and $\mathrm{CO}_{2}$ flux measurements}

Between 2009 and 2014, turbulent fluxes of $\mathrm{CO}_{2}$, water, heat and energy were measured at MEFO (Ortega et al., 2014) using the eddy covariance (EC) method (Baldocchi et al., 1988). An ultrasonic anemometer (CSAT3; Campbell Scientific, Logan, UT, USA) was mounted at $25.1 \mathrm{~m}$ of mea- surement height, along with a weather transmitter (WXT520; Vaisala, Vantaa, Finland) to measure absolute temperature and relative humidity. Air was drawn from the tower through a Teflon inlet line into the trailer and measured for $\mathrm{CO}_{2}$ and water vapor measurements using a closed-path IRGA (Li7000; Licor Biosciences, Lincoln, NE, USA). In this study, fluxes were averaged for $30 \mathrm{~min}$ intervals and underwent a quality control scheme including a test on stationarity and on the integral turbulence statistics (Foken and Wichura, 1996). Fluxes from periods failing both tests were removed from the data set $(13 \%)$; data failing only one test were flagged (53\%).

Analysis of the tower's suitability for micrometeorological measurements was performed previously during the BEACHON campaigns (Kaser et al., 2013a). Flux source regions (i.e., the flux footprint) for this campaign were computed using an analytical model (Hsieh et al., 2000), and the median $90 \%$ flux footprint recovery during unstable (blue) and stable (green) atmospheric conditions was spatially mapped (Fig. 3); $90 \%$ flux recovery stretched up to $1400 \mathrm{~m}$ (median $670 \mathrm{~m}$ ) upwind from the tower for unstable atmospheric conditions and $5000 \mathrm{~m}$ (median $2200 \mathrm{~m}$ ) for stable atmospheric conditions. Data from easterly winds were flagged for suspicious footprints due to the presence of a lightly traveled paved highway approximately $500 \mathrm{~m}$ away. Further data with $90 \%$ flux recovery exceeding $1.9 \mathrm{~km}$ were flagged due to possible source-sink inhomogeneity.

\section{Results}

\subsection{Alkene concentrations}

Ambient alkene concentrations, calculated as the average of the up and down bag reservoirs for the same hour-long period and reported as the end time, showed large fluctuations over the course of the field campaign (Fig. 4). Median and mean daily concentrations were the highest for ethene (318 and $303 \mathrm{ppt}$, respectively), followed by propene (176 and $182 \mathrm{ppt}$ ), isoprene (115 and $148 \mathrm{ppt}$ ), acetylene (79 and $86 \mathrm{ppt}$ ), butene (52 and $51 \mathrm{ppt}$ ) and benzene (43 and $44 \mathrm{ppt}$; Tables 1 and S2).

Ethene, propene, butene and isoprene concentrations exhibited clear diurnal cycles; the lowest concentrations were observed at nighttime, with a minimum typically occurring between 04:00 and 07:00 MST (Fig. 5, red points). From 07:00 MST onwards, concentrations sharply increased and reached maxima at 13:00 MST for ethene and propene. Butene and isoprene were also elevated during midday, although concentration peaks were not as pronounced. During the afternoon, all of these compounds showed a slow decrease towards the nighttime minima. In contrast, benzene showed only a minor enhancement in concentration during the daytime, and acetylene concentrations showed no measurable diurnal cycle (Figs. 4 and 5). 


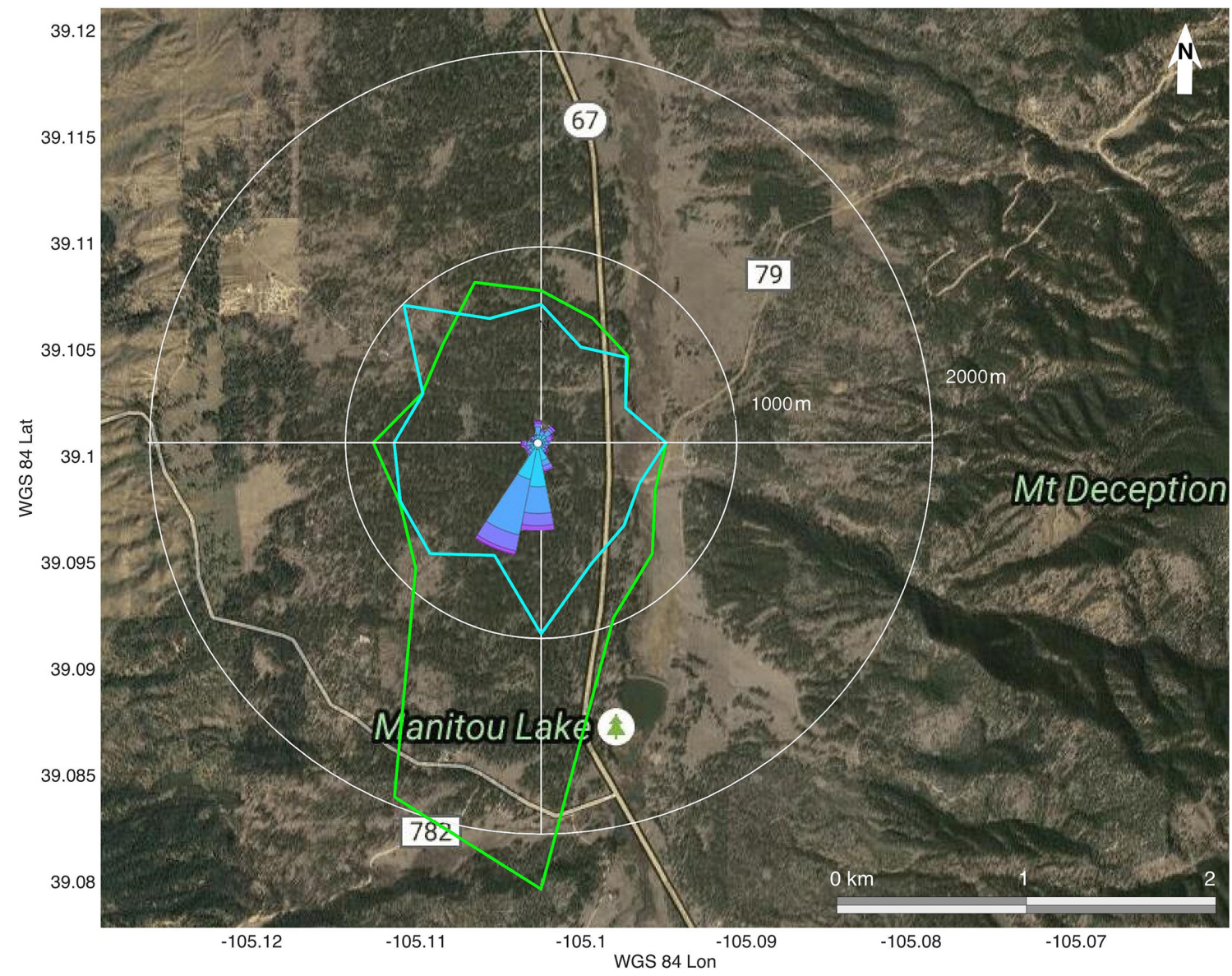

Figure 3. Aerial image of the tower site and the flux footprint (median $90 \%$ recovery) during unstable (blue) and stable (green) atmospheric conditions in this field campaign. Background imagery from Google Earth.

Gaps in the measurement period complicate the picture for larger-timescale fluctuations in concentrations. The highest concentrations for ethene, propene and butene occurred between days 198 and 206 during midday. Ethene and propene also had high concentrations in the early measurement period between days 176 and 181 when butene concentrations were not monitored. The highest daytime isoprene concentrations occurred between days 200 and 208, also during midday. Acetylene had two periods of higher concentrations, between days 197 and 201 and days 220 and 223, with the highest concentrations occurring either in the daytime or at night. Benzene showed no obvious temporal trends.

\subsection{Alkene fluxes}

Approximately 450 net fluxes (Fig. 6) were quantified over the course of the summer, of which $19 \%$ were critically flagged and omitted from further analysis (Supplement). Ethene had the largest overall median and mean flux (46 and $71 \mu \mathrm{g} \mathrm{m}^{-2} \mathrm{~h}^{-1}$, respectively), followed by propene (36 and $\left.59 \mu \mathrm{g} \mathrm{m}^{-2} \mathrm{~h}^{-1}\right)$, butene (12 and $23 \mu \mathrm{g} \mathrm{m}^{-2} \mathrm{~h}^{-1}$ ) and isoprene (0.6 and $14 \mu \mathrm{g} \mathrm{m}^{-2} \mathrm{~h}^{-1}$; Tables 1 and S2).
The time series of alkene fluxes show distinct diurnal patterns of emissions that are similar for ethene, propene and butene (Fig. 5, blue points). Median and mean daytime emissions were large for ethene (123 and $123 \mu \mathrm{g} \mathrm{m}^{-2} \mathrm{~h}^{-1}$, respectively), followed by propene (95 and $104 \mu \mathrm{g} \mathrm{m}^{-2} \mathrm{~h}^{-1}$ ),

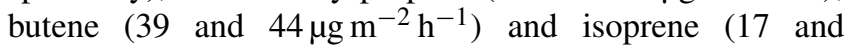
$32 \mu \mathrm{g} \mathrm{m}^{-2} \mathrm{~h}^{-1}$ ), but these elevated fluxes were concentrated between 10:00 and 17:00 MST. In general, light alkene fluxes were low (but generally positive) at nighttime, with a rapid rise during the morning and a rapid drop in the evening. Isoprene fluxes on average showed a similar pattern but decreased earlier in the afternoon (15:00 MST) and had roughly zero flux at nighttime. In contrast, acetylene and benzene showed no diurnal flux patterns and scatter around zero: $1 \pm 13 \mu \mathrm{g} \mathrm{m}^{-2} \mathrm{~h}^{-1}$ for acetylene and $-2 \pm 17 \mu \mathrm{g} \mathrm{m}^{-2} \mathrm{~h}^{-1}$ for benzene (Fig. 5, Table 1).

In addition to the diurnal patterns, multiday ( $\sim 5$ day) fluctuations were visible in the measured peak daytime fluxes for the alkenes (Fig. 6). Daytime maximum emissions rose and fell $50 \%$ between days 198 and 205 and again between days 215 and 220 . The pattern resembles the broad temporal trends in temperature, radiation and water flux (Fig. 6). 

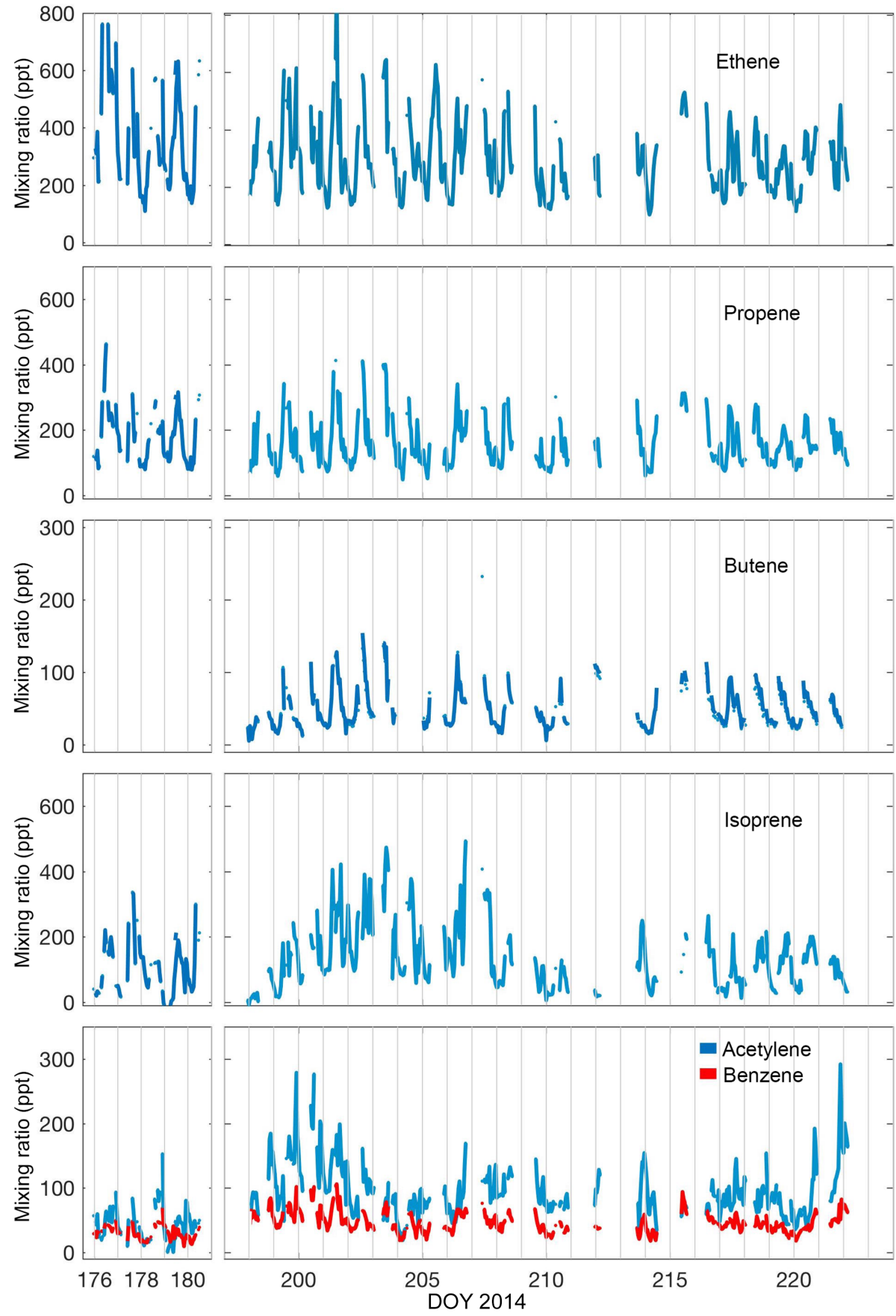

Figure 4. Hourly averaged ambient concentrations of alkenes, acetylene and benzene at Manitou Forest. Periods of missing data are due to instrumental maintenance or incomplete chromatography.

Gap filling REA fluxes (Fig. 6) using artificial neural networks (i.e., modeled results) removes the temporal bias in averaging the quality-controlled observations. The ANN-derived gap filling of missing hourly data yields $20 \%$ higher median (Table 1) and 7-8\% higher mean (Table S2) emission rates for the light alkenes. However, these differences between groups of modeled and observed fluxes were nonsignificant (ANOVA, $\alpha=0.05$ ), suggesting that the selectivity of quality-controlled measurements might lead to only a minor underprediction of diurnal averages. When negative alkene fluxes were measured, they usually failed quality control owing to stable nocturnal atmospheric conditions; however, a limited number (small proportion) of quality-ensured fluxes suggest apparent uptake at night, 


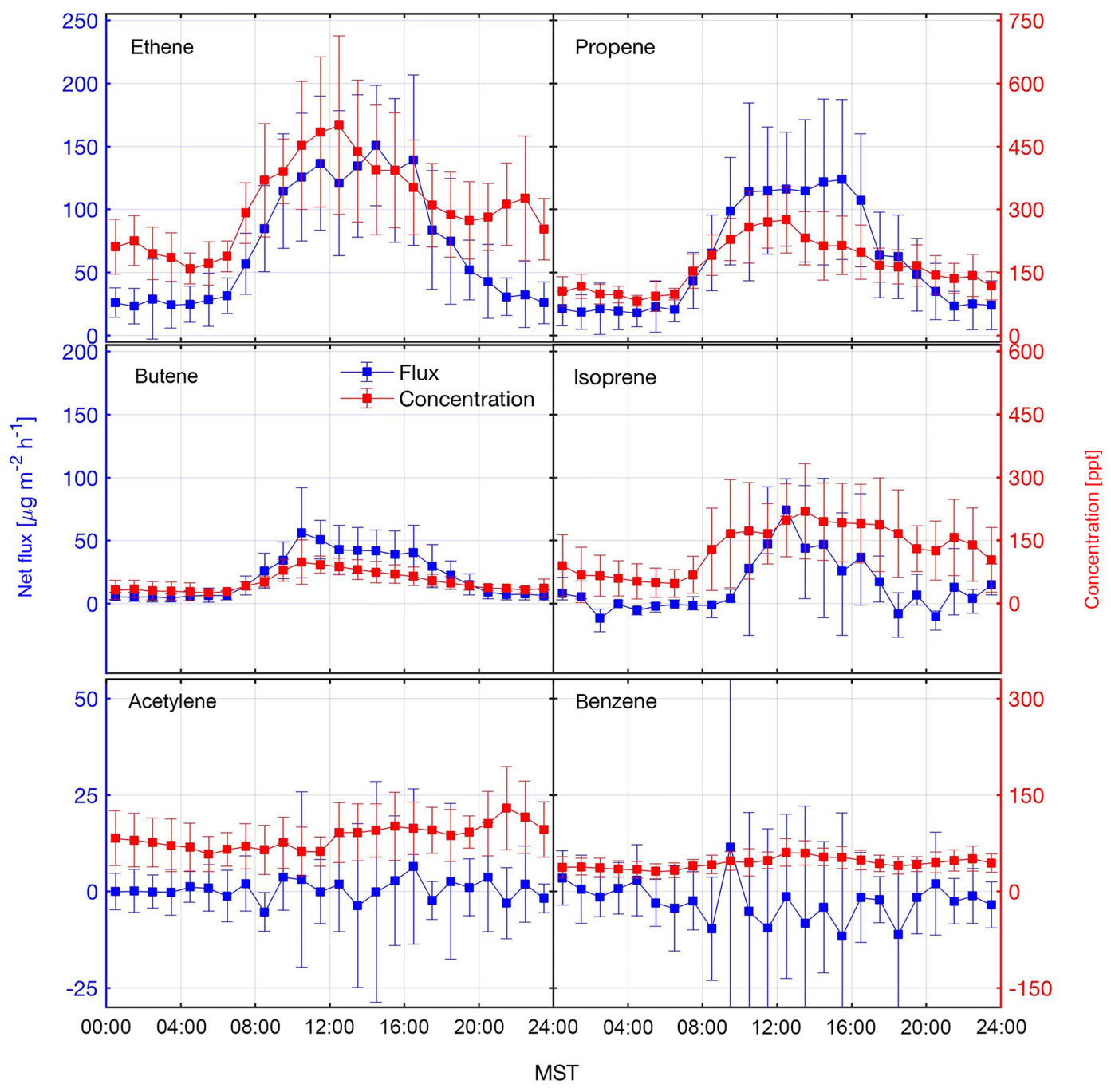

Figure 5. Averaged diurnal patterns of alkene, acetylene and benzene concentrations (red) and their fluxes (blue) with error bars indicating $\pm 1 \sigma$.

with $n=12(3.3 \%)$ for ethene $\left(-48.3 \mu \mathrm{g} \mathrm{m}^{-2} \mathrm{~h}^{-1}\right), n=24$ $(8 \%)$ for propene $\left(-28 \mu \mathrm{g} \mathrm{m}^{-2} \mathrm{~h}^{-1}\right), n=12(3.1 \%)$ for butene $\left(-8.7 \mu \mathrm{g} \mathrm{m}^{-2} \mathrm{~h}^{-1}\right)$ and $n=124(34 \%)$ for isoprene $\left(-20.9 \mu \mathrm{g} \mathrm{m}^{-2} \mathrm{~h}^{-1}\right)$ being larger than flux detection limits. Negative fluxes were too infrequent and small to be captured in ANN model predictions for the light alkenes (Table 1).

\subsection{Eddy covariance: $\mathrm{CO}_{2}, \mathrm{H}_{2} \mathrm{O}$ and energy fluxes}

Over the sampling period (24 June-9 August 2014), Manitou Forest acted as a net $\mathrm{CO}_{2}$ source of $2.6 \mathrm{~g} \mathrm{~m}^{-2} \mathrm{~d}^{-1}$ on average (Fig. 6). Characteristic diurnal flux patterns show nighttime to morning respiration $\left(2-8 \mu \mathrm{mol} \mathrm{m}^{-2} \mathrm{~s}^{-1}\right)$ and net $\mathrm{CO}_{2}$ uptake (up to $-8.6 \mu \mathrm{mol} \mathrm{m} \mathrm{m}^{-2} \mathrm{~s}^{-1}$ ) between 09:00 and 18:00 MST. A simple one-level storage term evaluation was performed (Rannik et al., 2009). The venting of stored $\mathrm{CO}_{2}$ was on the order of magnitude of measured EC fluxes in the morning (06:00-08:00 MST), leading to apparent emis- sion during the onset of turbulence. Storage occurred at night (19:00-24:00 MST), leading to an underrepresentation in measured nighttime respiration on the order of $\sim 25 \%$. Over the course of a day, the positive and negative storage terms cancel each other out.

The diurnal $\mathrm{CO}_{2}$ flux cycle increased in amplitude following the onset of significant seasonal rainfall. In the first half of the measurement period, 24 June through 11 July (DOY 175 through 192), daily maximum and minimum $\mathrm{CO}_{2}$ fluxes were relatively small, averaging $4.4 \pm 1.4$ and $-3.1 \pm$ $1.7 \mu \mathrm{mol} \mathrm{m}{ }^{-2} \mathrm{~s}^{-1}$, respectively. Following a strong rain event on 12 July (DOY 193, between 15:00 and 17:00 MST), these averaged $7.5 \pm 2.4$ and $-5.8 \pm 1.6$, respectively, through the end of the campaign on 9 August (DOY 193 to 221). During this latter time period, numerous significant rainfall events also occurred (Fig. 6). 

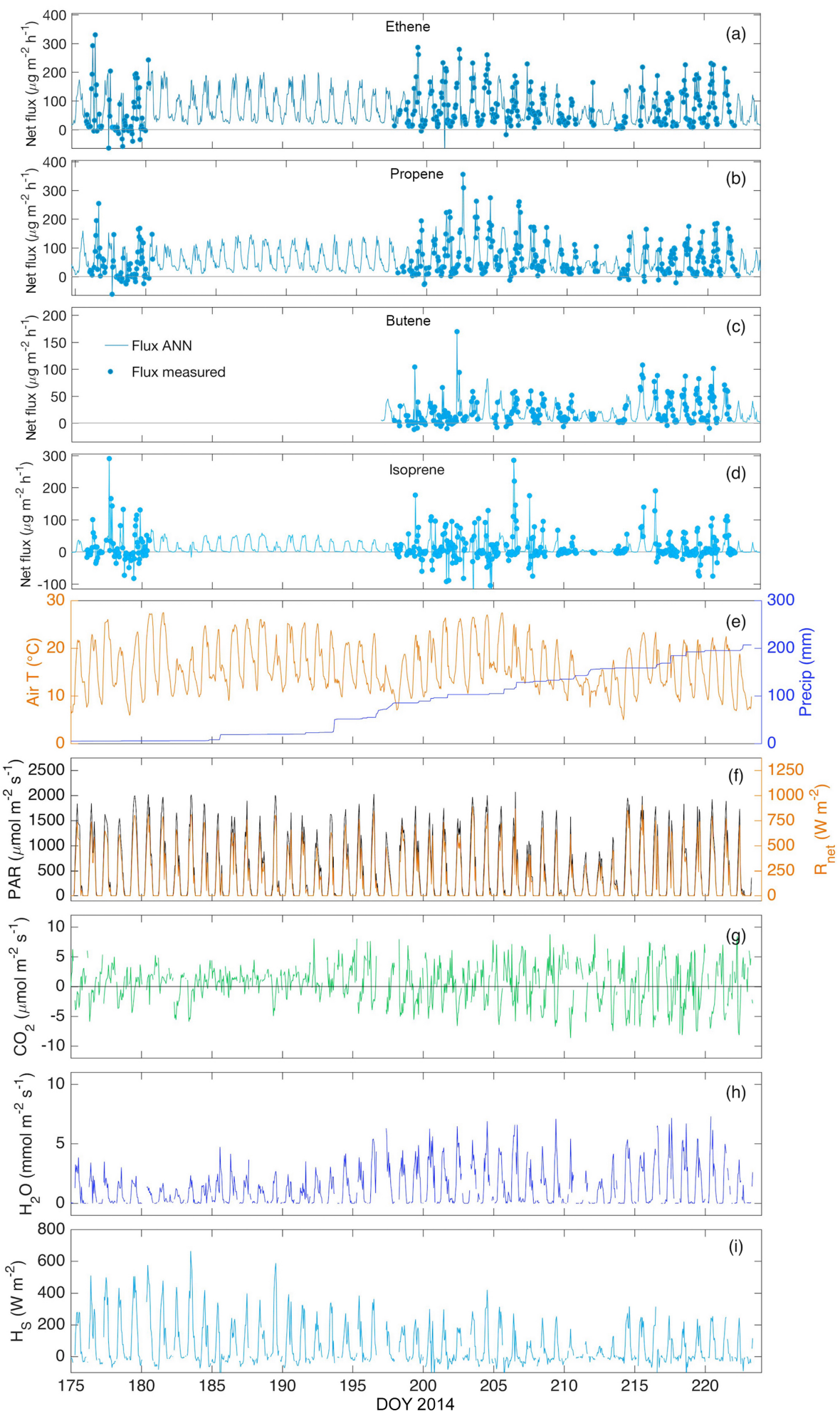

Figure 6. Net fluxes of (a) ethene, (b) propene, (c) butene and (d) isoprene based on REA (symbols) and gap filled with ANN (lines). Measurements of (e) air temperature and cumulative precipitation and (f) PAR and net radiation. Eddy covariance measurements of (g) net $\mathrm{CO}_{2}$ flux, (h) water vapor flux and (i) sensible heat flux. 
Table 1. Measurements of light alkenes, isoprene, acetylene and benzene at Manitou Forest between 24 June and 9 August 2014 , including the median (10th and 90th percentile) of observed concentrations, measured fluxes, ANN gap-filled fluxes and average daytime fluxes. ANN fluxes are for the sampling period 25 June-9 August 2014. Understory fluxes measured on 2 September 2014 (median, 10th and 90th percentiles) and overall flux detection limits are also shown. Mean and standard deviations of these measurements and model results are reported in Table $\mathrm{S} 2$.

\begin{tabular}{llrrrrrr}
\hline & $\begin{array}{r}\text { Concentration } \\
\text { median } \\
(\mathrm{ppt})\end{array}$ & $\begin{array}{r}\text { Measured } \\
\text { flux } \\
\left(\mu \mathrm{g} \mathrm{m}^{-2} \mathrm{~h}^{-1}\right)\end{array}$ & $\begin{array}{c}\text { ANN flux }^{\mathrm{a}} \\
\left(\mu \mathrm{g} \mathrm{m}^{-2} \mathrm{~h}^{-1}\right)\end{array}$ & $\begin{array}{r}\text { Daytime flux } \\
(\text { measured }) \\
\left(\mu \mathrm{g} \mathrm{m}^{-2} \mathrm{~h}^{-1}\right)\end{array}$ & $\begin{array}{r}\text { Flux } \\
\text { understory } \\
\left(\mu \mathrm{g} \mathrm{m}^{-2} \mathrm{~h}^{-1}\right)\end{array}$ & $\begin{array}{r}\text { Detection } \\
\left(\mu \mathrm{g} \mathrm{m}^{-2} \mathrm{~h}^{-1}\right)\end{array}$ \\
\hline $\mathrm{C}_{2} \mathrm{H}_{4}$ & Ethene & $318[153,574]$ & $46.4[8,173]$ & $55.3[11,173]$ & $123[32,224]$ & $-33.8[-63,-1.0]$ & 4.1 \\
$\mathrm{C}_{3} \mathrm{H}_{6}$ & Propene & $176[101,301]$ & $35.6[3,151]$ & $43.0[5,153]$ & $94.5[20,192]$ & $-40.3[-62,-5]$ & 4.7 \\
$\mathrm{C}_{4} \mathrm{H}_{8}$ & Butene & $52[29,103]$ & $12.0[0,59]$ & $15.6[1,61]$ & $39.1[15,80]$ & $-10.4[-20,-5]$ & 4.1 \\
$\mathrm{C}_{5} \mathrm{H}_{8}$ & Isoprene & $115[31,297]$ & $0.6[-23,80]$ & $3.6[-4,44]$ & $17[-35,109]$ & $110[12,202]$ & 3.4 \\
$\mathrm{C}_{2} \mathrm{H}_{2}$ & Acetylene & $79[31,136]$ & $-0.4[-9,13]$ & $\mathrm{n} / \mathrm{a}$ & $-0.2[-15,15]$ & $1.2[-9,10]$ & 13.6 \\
$\mathrm{C}_{6} \mathrm{H}_{6}$ & Benzene & $43[25,68]$ & $-1.6[-16,12]$ & $\mathrm{n} / \mathrm{a}$ & $-3.9[-28,16]$ & $-2[-13,1]$ & 5.4 \\
\hline
\end{tabular}

${ }^{\mathrm{a}}$ Gap filled using artificial neural networks (ANNs); ${ }^{\mathrm{b}}$ 10:00-18:00 MST.

$\mathrm{H}_{2} \mathrm{O}$ fluxes have a characteristic diurnal pattern, with negligible fluxes during nighttime, a sharp increase during sunrise (07:00 MST), maxima at 12:00 MST and a steady decrease during afternoon. On overcast days, peak emissions were on the order of $1.2 \mathrm{mmol} \mathrm{m}^{-2} \mathrm{~s}^{-1}$, whereas on sunny days fluxes reached up to $7.8 \mathrm{mmol} \mathrm{m}^{-2} \mathrm{~s}^{-1} \cdot \mathrm{H}_{2} \mathrm{O}$ storage was found to be negligible. As with $\mathrm{CO}_{2}$, the amplitude of water vapor fluxes increased from 12 July (DOY 193) onwards. Average daily maximum water vapor fluxes were $2.9 \pm 0.2$ and $5.4 \pm 0.7 \mathrm{mmol} \mathrm{m}^{-2} \mathrm{~s}^{-1}$ for the measurement periods before and after 12 July, respectively.

Sensible heat fluxes $\left(\mathrm{H}_{S}\right)$ ranged from -100 to $500 \mathrm{~W} \mathrm{~m}^{-2}$. Typical diurnal patterns indicated nighttime inversions from 20:00-07:00 MST and peak emissions at 12:00 MST. Computing the Bowen ratio $(\mathrm{B}=$ sensible heat divided by latent heat fluxes) gives insight into the ecosystem's response to water availability. In the dry period prior to day 193 , B was strictly $>1($ median $=2)$, which is typical for semiarid water-limited ecosystems. During this time, evaporation was restricted, favoring elevated sensible heat flux. After rainfall events, B dropped below 1 (median $=0.4$ ) due to higher latent heat fluxes and hence less sensible heat flux.

\subsection{Correlations}

For the following analysis, correlations are quantified between two independent variables using the Pearson correlation coefficient $(\rho)$. Above-canopy concentrations of ethene, propene and butene were highly correlated $(0.73<\rho \leq$ 0.88 ), whereas correlations including isoprene were slightly weaker ( $\rho=0.4-0.5$; red and black dots, Fig. 7). Concentrations of these light alkenes and isoprene were poorly correlated with those of acetylene or benzene $(\rho<0.5)$; however, benzene and acetylene showed a strong correlation with each other $(\rho=0.78)$. For the correlated pairs, median molar concentration ratios were propene/ethene
(0.55), butene/ethene (0.18), butene/propene (0.31) and benzene / acetylene $(0.51)$.

Similar to the concentrations, the net fluxes of ethene, propene and butene showed high correlation coefficients with each other $0.52<\rho \leq 0.93$, whereas correlations with isoprene, acetylene and benzene were weak $\rho<0.2$. Unlike their concentrations, benzene and acetylene fluxes were not correlated $(\rho=0.24)$. The strong correlation between ethene and propene fluxes was particularly notable $(\rho=$ 0.93). The median of mass flux ratios (excluding those $<$ LDL) were propene / ethene (0.87), butene / ethene $(0.31)$ and butene / propene (0.35).

\subsection{Understory fluxes}

The understory flux measurements on 2 September 2014 can help partition the above-canopy fluxes between surface and canopy sources. Of the 10 REA flux samples collected that day, 8 flux samples exceeded the $\sigma_{w}$ threshold of $0.4 \mathrm{~m} \mathrm{~s}^{-1}$; the 2 samples that fell beneath the threshold occurred during the early morning hours (Fig. S2). For the light alkenes, the understory fluxes greatly contrasted with the above-canopy fluxes. The understory REA measurements showed detectable consumption overall for ethene, propene and butene as opposed to the large emissions observed from the above-canopy fluxes (Table 1, Fig. S3).

In contrast, the isoprene, acetylene and benzene fluxes were in similar ranges to the above-canopy fluxes. Isoprene showed relatively large emissions during the day at the surface, which are in the upper range of observed daytime emissions from the above-canopy measurements. Acetylene and benzene showed small fluxes that scattered around zero, similar to the above-canopy measurements. 


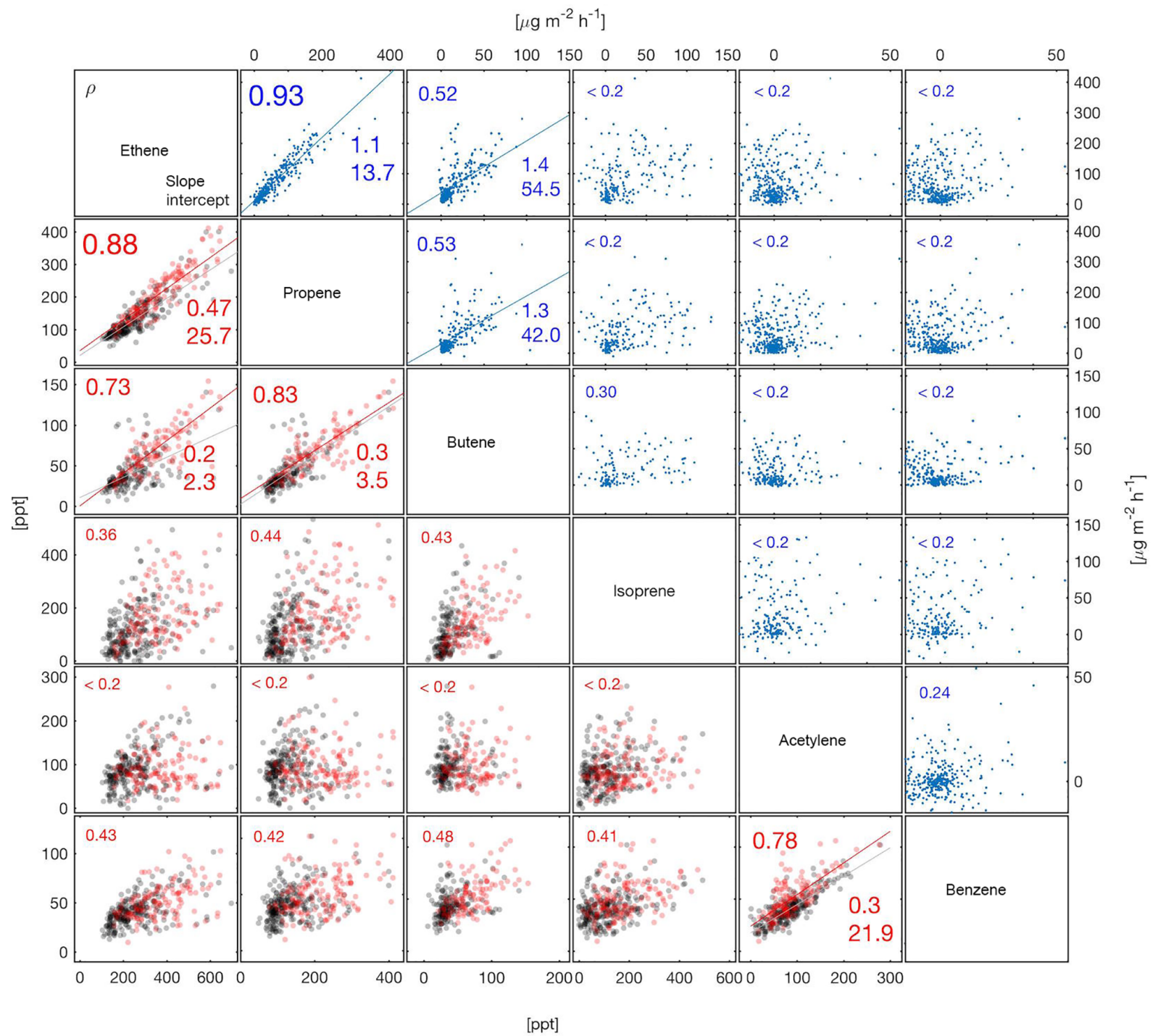

Figure 7. Correlation matrix of light alkene, isoprene, acetylene and benzene fluxes (blue), daytime concentrations (red) and nighttime concentrations (black). Numbers denote the Pearson correlation coefficient ( $\rho$, top left) and the slope and intercept (bottom right numbers) for the linear fits in plots where $\rho>0.5$. Negative fluxes for the light alkenes ( 1.3 to $2.3 \%$ of the light alkene fluxes) are excluded from the plot and the regression statistics; positive fluxes $<\mathrm{LDL}$ are not excluded.

\section{Discussion}

The magnitude and temporal pattern of these light alkene emissions reveal several aspects of trace gas biogeochemistry and atmospheric chemistry from this ecosystem. First, the origin of the light alkenes is deduced to be local and biogenic through an analysis of the flux footprint combined with a comparative analysis with other VOCs measured at the site. Second, the results can be put in the context of the prior BEACHON campaigns to demonstrate the relative importance of light alkenes in the overall emission of reactive VOCs from this ponderosa pine ecosystem. Third, the Manitou Forest results can be compared with the few literature measurements of light alkene fluxes in other ecosys- tems. Fourth, modeled fluxes can be compared to the light and temperature responses for other BVOCs. Finally, the results provide insights regarding the modeling capabilities of global vegetation BVOC emission models.

\subsection{The origin of the light alkenes}

While isoprene is well known to be a biogenic volatile organic compound, the biogenic sources for the light alkenes are not as well determined. In this study, ethene, propene and butene appear to originate from local sources that are also biogenic in origin, in particular from the forest canopy.

The large diurnal fluctuations of both ambient concentrations and net fluxes of the alkenes follow sunlight and tem- 
Table 2. Fitted coefficients for light response flux (with $90 \%$ confidence intervals) in Eq. (4).

\begin{tabular}{lrrrr}
\hline Response & $F(\mathrm{PAR})$ & & & \\
\hline Compound & $F_{1000}$ & $\alpha\left(\times 10^{-3}\right)$ & $C_{\mathrm{L} 1}$ & $r^{2}$ \\
& {$\left[\mu \mathrm{g} \mathrm{m}^{-2} \mathrm{~h}^{-1}\right]$} & & & \\
\hline Ethene & 130 & $1.716[1.097-3.379]$ & $1.1577[1.0231-1.3385]$ & 0.88 \\
Propene & 110.7 & $1.523[0.5949-2.011]$ & $1.1969[1.0207-1.5171]$ & 0.83 \\
Butene & 37.7 & $1.263[0.240-2.055]$ & $1.2769[1.1199-2.2605]$ & 0.86 \\
Isoprene & 42.7 & $0.681[-0.1-1.4]$ & $1.7974[0.65574-3.7002]$ & 0.8 \\
MBO $^{\mathrm{a}}$ & & 1.1 & 1.44 & \\
MBO $^{\mathrm{b}}$ & & 1.1 & 1.37 & \\
MBO + isoprene $^{\mathrm{c}}$ & & 1.1 & 1.35 & \\
\hline
\end{tabular}

${ }^{a}$ Harley et al. (1998); ${ }^{b}$ Schade and Goldstein (2001); ${ }^{\mathrm{c}}$ Kaser et al. (2013a).

perature cycles, which is typical for biogenic VOCs. For example, prior studies at Manitou Forest showed that summertime VOCs with diurnal cycles were predominantly biogenic, with the highest contributions from 2-methyl-3-buten-2-ol (232-MBO or MBO), methanol, ethanol, acetone, isoprene and, to a lesser extent, monoterpenes (mostly $\alpha$-pinene, $\beta$ pinene and $\Delta$-3-carene; Kim et al., 2010; Greenberg et al., 2012). Diurnal patterns of alkene concentrations agree with observations of the sum of $\mathrm{MBO}+$ isoprene. Monoterpene emissions are biogenic but occur throughout the day and night; their diurnal concentration pattern is inverted, with a buildup in the shallower boundary layer over nighttime and depletion during daytime, the latter due to a combination of dilution in the growing boundary layer and reactivity with $\mathrm{O}_{3}$ and $\mathrm{OH}$ (Kaser et al., 2013b).

In contrast, no such diurnal patterns in concentration are observed for the primarily anthropogenic compounds (acetylene and benzene), and their fluxes are near zero (Table 1). Consequently, correlations between the light alkenes and either acetylene or benzene are poor (concentrations) or nonsignificant (fluxes). Acetylene is considered to be a tracer of combustion originating from biomass burning or urban areas (Xiao et al., 2007). The two general periods of elevated ambient acetylene concentrations, between days 197 and 201 and days 220 and 223, did not correspond to the highest concentrations of the light alkenes. Also, elevated acetylene concentrations typically occurred at nighttime, not at midday like the biogenic VOCs. Benzene appeared to have a slight diurnal fluctuation, but this compound may also have a minor biogenic source in addition to its anthropogenic sources (Misztal et al., 2015). In prior studies at Manitou Forest, it was shown that on days with long-range transport from the Front Range cities (Colorado Springs, Denver), anthropogenic VOCs were present, although typically at low concentrations, and no significant local anthropogenic emissions were detected in the area around the site (Ortega et al., 2014).

The REA method requires a measurable concentration difference based on vertical winds. Thus, the observation of alkene emissions points to a local source, and the flux foot- print during the daytime is predominantly ponderosa pine forest. The vertical concentration gradient of any source outside of the flux footprint would be erased because of mixing by the time it reached the tower, perhaps generating elevated concentrations but no measurable flux. The benzene and acetylene measurements support this; elevated concentrations in ambient air were occasionally observed for these compounds, presumably from distant anthropogenic sources, but they were not associated with emissive fluxes at the site.

The understory measurements demonstrate that these light alkenes are emitted from the forest canopy, not from the surface litter or soils (Table 2). In fact, light alkenes showed a small downward flux to the surface, suggesting potential consumption. Very small emission rates of light alkenes from a boreal forest floor in Finland $\left(<1.8 \mu \mathrm{g} \mathrm{m}^{-2} \mathrm{~h}^{-1}\right.$ for ethene, $<0.5 \mu \mathrm{g} \mathrm{m}^{-2} \mathrm{~h}^{-1}$ for propene and $<0.05 \mu \mathrm{g} \mathrm{m}^{-2} \mathrm{~h}^{-1}$ for cis2-butene; Hellén et al., 2006) may also be consistent with the present study, given that the light alkene emissions appear to be from the canopy, not from the forest floor.

In contrast to the light alkenes, surface isoprene emissions were relatively large and comparable in magnitude to the above-canopy emissions during the growing season. The understory included grasses and herbaceous flower plants (forbs), which were not predicted to be significant sources of isoprene. Leaf and needle litter emissions of BVOCs were measured from ponderosa pine (the dominant tree species) at Manitou Forest previously, and a compound with the ion $m / z=69$ (such as isoprene) was measured using PTR-MS. This compound was tentatively identified as pentanal because of the lack of known isoprene-emitting vegetation at the site (Greenberg et al., 2012), but our measurements suggest that a small local isoprene surface source exists. The relatively small fluxes of isoprene are consistent with BEACHON campaign measurements, which showed that isoprene amounted to $\sim 10-20 \%$ of MBO concentrations at Manitou Forest (Karl et al., 2014). Benzene and acetylene show negligible fluxes in the understory, similar to abovecanopy fluxes. Taken together, these observations suggest 
that the canopy is the source for the light alkenes and the understory is a source for isoprene.

A direct comparison between tower-based and understory fluxes cannot be made because only one REA system was available. However, the light (1300-1700 $\left.\mu \mathrm{mol} \mathrm{m}^{-2} \mathrm{~s}^{-1}\right)$ and temperature $\left(20-26^{\circ} \mathrm{C}\right)$ conditions during the understory measurements on 2 September 2014 can be inserted into the temperature and PAR parameterizations from the towerbased measurements to calculate expected fluxes (Sect. 5.4). Doing this yields a predicted isoprene emission of $91 \pm$ $57 \mu \mathrm{g} \mathrm{m}^{-2} \mathrm{~h}^{-1}$, which is within $20 \%$ of the averaged measured understory flux (Tables 1 and S2) and supports the hypothesis that the understory is the dominant source for isoprene.

\subsection{In the context of prior BEACHON campaigns}

We can assess the relative importance of light alkenes in the overall emission of reactive VOCs from this ponderosa pine ecosystem by comparing the light alkene emissions measured in this study with the other BVOCs measured during the BEACHON campaigns. In order to do this, it is important to place 2014 in the context of prior years using ecological parameters measured across all of these years. Eddy covariance flux measurements of $\mathrm{CO}_{2}$ and heat allow for this type of comparison: $\mathrm{CO}_{2}$ fluxes, PAR and net radiation flux observed from June-August 2014 (Fig. 6) were similar to observations made during the 2008-2013 BEACHON campaigns both in magnitude and seasonal pattern (Ortega et al., 2014). For example, the summer net ecosystem exchange (NEE) is usually positive, while the spring NEE is negative. Also, the increase in $\mathrm{CO}_{2}$ emissions following the onset of precipitation has been observed at this site in previous years. This has been attributed to the "Birch effect" found in semiarid, Mediterranean and African ecosystems, whereby precipitation triggers a burst of organic matter decomposition with subsequent $\mathrm{CO}_{2}$ emissions, significantly reducing or inverting NEE in forest ecosystems (Jarvis et al., 2007).

The overall seasonally averaged sum of ethene, propene and butene flux measurements is $\sim 150 \mu \mathrm{g} \mathrm{m}^{-2} \mathrm{~h}^{-1}$, and this amount is substantial even in comparison to the other BVOCs previously measured at the site. For example, the daytime average (10:00-18:00 MST) flux of combined light alkenes was $\sim 270 \mu \mathrm{g} \mathrm{m}^{-2} \mathrm{~h}^{-1}$. This is approximately $15 \%$ of the combined $\mathrm{MBO}+$ isoprene flux of $1.84 \mathrm{mg} \mathrm{m}^{-2} \mathrm{~h}^{-1}$ (combined because the PTR-MS measurements were not able to fully discriminate between these compounds), and it is twothirds of the methanol emissions $\left(0.42 \mathrm{mg} \mathrm{m}^{-2} \mathrm{~h}^{-1}\right.$; Kaser et al., 2013a). Thus, the light alkenes contribute a significant amount of reactive carbon to the atmosphere at this coniferous forest ecosystem and may even play a bigger role in ecosystems that do not emit MBO.

To assess the relative importance of the light alkenes and isoprene to the total $\mathrm{OH}$ reactivity of the BVOCs, we utilized the daytime fluxes from this study compared with the

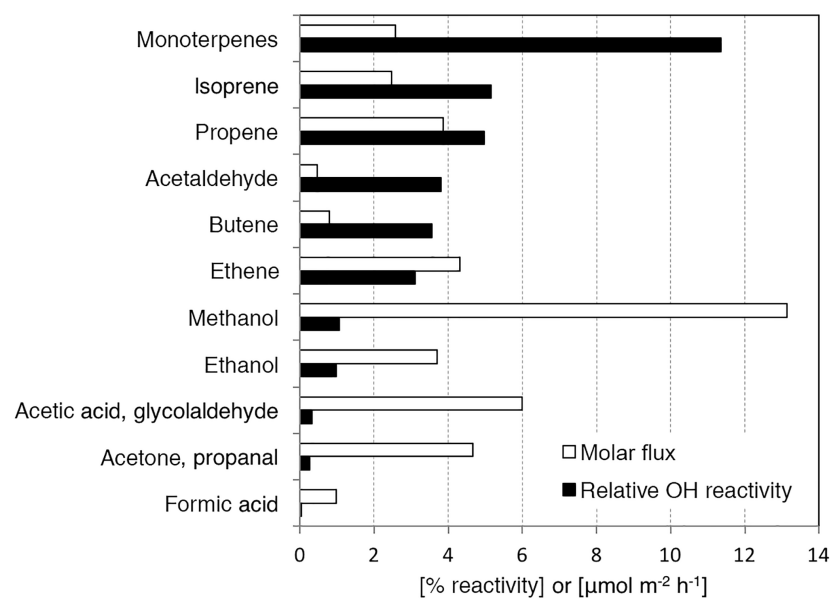

Figure 8. Daytime averaged molar flux and relative $\mathrm{OH}$ reactivity for the major known BVOCs emitted at Manitou Experimental Forest. MBO (not shown) contributes $21 \mu \mathrm{mol} \mathrm{m}{ }^{-2} \mathrm{~h}^{-1}$ and $65 \%$ of the $\mathrm{OH}$ reactivity.

MBO, methanol, monoterpene, acetic acid, glycolaldehyde, acetaldehyde, ethanol, acetone, propanal and formic acid fluxes reported previously for this site (DiGangi et al., 2011; Kaser et al., 2013a). Multiplying the mixing ratios of these compounds by their $\mathrm{OH}$ rate constants provides a measure of relative $\mathrm{OH}$ reactivities (Ryerson et al., 2003; Fantechi et al., 1998; Ravishankara and Davis, 1978; Atkinson et al., 1986, 1997; Baulch et al., 1994; Huang et al., 2009; Picquet et al., 1998). We utilized fluxes instead of concentrations to provide a measure of $\mathrm{OH}$ reactivity that is independent of elevated concentrations associated with pollution events and more representative of site-specific sources. Accordingly, the dominant $\mathrm{BVOC}$ for $\mathrm{OH}$ reactivity is $\mathrm{MBO}$, accounting for $65 \%$, followed by monoterpenes at $11 \%$ and isoprene at $5 \%$ (Fig. 8). Ethene, propene and butene accounted for 3, 5 and $4 \%$ of the $\mathrm{OH}$ reactivity, respectively. Combined, the light alkenes accounted for $11.6 \%$ of the total $\mathrm{OH}$ reactivity, which is comparable to the monoterpenes and second only to MBO. Thus, the light alkenes are an important component of the atmospheric chemistry of ponderosa pine forests. It is possible that unmeasured or underestimated emissions of the light alkenes can contribute to the problem of missing $\mathrm{OH}$ reactivity observed in other forests, as the reactive source for the missing $\mathrm{OH}$ has the temperature response characteristics of a BVOC (Di Carlo et al., 2004; Mogensen et al., 2011; Nölscher et al., 2013).

\subsection{Literature comparison of light alkene fluxes}

Net ecosystem fluxes of light alkenes have been reported for one other forested site: a temperate deciduous forest in Massachusetts (Harvard Forest; $42^{\circ} \mathrm{N}, 72^{\circ} \mathrm{W}$; Goldstein et al., 1996). Using a flux gradient method, average emission fluxes were derived for ethene, propene and butene (1- 
butene) of 44.1, 28.4 and $13.8 \mu \mathrm{g} \mathrm{m}^{-2} \mathrm{~h}^{-1}$, calculated as the integrated mean diurnal fluxes between 1 June and 31 October 1993. In the present study, observed Manitou Forest emissions were larger by factors of 1.6 to 2.1 (71.3, 59.0 and $22.8 \mu \mathrm{g} \mathrm{m}^{-2} \mathrm{~h}^{-1}$, respectively). However, this study focused on the summer months of July-August 2014, and the much higher fluxes are partly a consequence of averaging fluxes over a period of higher temperature and PAR. A simple extrapolation for the whole season at Manitou Forest, assuming linear increases and decreases from/to zero during the shoulder months, still yields 30-70\% larger seasonal fluxes, suggesting that the coniferous Manitou Forest indeed emits more per unit area than the deciduous Harvard Forest. A more detailed model extrapolation for the shoulder season is applied in Sect. 5.5.

In both studies, the fluxes of these alkenes were correlated with each other, although with slightly different ratios. Goldstein et al. (1996) report molar ratios of emissions of ethene and butene versus propene of $1.8 \pm 0.22$ (SD error) and $0.41 \pm 0.06$, respectively, whereas this study yielded ratios of $1.1 \pm 0.17$ and $0.52 \pm 0.14$ (SD error), respectively. While the butene/ propene ratio appears to be similar, a key difference is that the butene isomer identified by Goldstein et al. (1996) was 1-butene, whereas in this study the butene isomer is tentatively identified as cis-2-butene.

Strong diurnal cycles of ethene, propene and butene fluxes were observed in both forests, but MEFO fluxes more closely tracked temperature than incident light, whereas Harvard Forest exhibited the reverse. This was illustrated both by the temporal synchronicity and the stronger correlation between the alkene fluxes and ambient temperature (for MEFO) or PAR (for Harvard Forest; see Sect. 5.4). At MEFO, ambient temperature usually peaked $1-2 \mathrm{~h}$ after PAR starts declining, similar to the alkene fluxes.

A brief comparison can be made with other observed biogenic emissions of light alkenes. Ethene emission rates from plant shoots compiled by Sawada and Totsuka (1986) averaged $1.5 \mathrm{ng}$ of ethene per gram fresh weight (gfrw) per hour, with a range of $0.6-3.2 \mathrm{ng}(\mathrm{gfrw})^{-1} \mathrm{~h}^{-1}$. Emission rates were combined with biomass and surface area estimates of biomes to derive a net areal flux from coniferous forests for the growing season of $29.8 \mu \mathrm{g} \mathrm{m}^{-2} \mathrm{~h}^{-1}$ from plant shoots and leaves. This is roughly $40 \%$ of the average $\left(71 \mu \mathrm{g} \mathrm{m}^{-2} \mathrm{~h}^{-1}\right)$ and $65 \%$ of the median $\left(46 \mu \mathrm{g} \mathrm{m}^{-2} \mathrm{~h}^{-1}\right)$ ethene flux measured here. Given the fact that the prior study was based largely on a very limited number of laboratory incubations of nonarboreal species, it is remarkable that the emission rates are within a factor of 3 of each other. On the other hand, the emission rates from coniferous forests during the warmest part of the summer appear to exceed the previously assumed upper range of emissions.

\subsection{Light and temperature responses}

There is a striking similarity in the multiday patterns observed in both the biogeochemical fluxes and environmental parameters at MEFO. The mesoscale temporal patterns in the fluxes are illustrated by a rise and fall of peak midday values (Fig. 6), such as the one occurring between DOY 198 and 212 followed by another between DOY 202 and 223. A similar pattern is evident in the peak midday $\mathrm{H}_{2} \mathrm{O}$ flux, the maximum daily air temperature and the net radiation and/or PAR. These trends were measured independently with separate instruments using different methods. The relationship between the fluxes and environmental parameters suggests that sunlight and temperature control the variability in the alkene fluxes and evapotranspiration rates.

To describe temperature and light responses, alkene fluxes have been averaged into bins of (a) $200 \mu \mathrm{mol} \mathrm{m}^{-2} \mathrm{~s}^{-1}$ PAR and (b) $2{ }^{\circ} \mathrm{C}$ temperature classes (Fig. 9). The light response flux, $F$ (PAR), was parameterized according to Eq. (4) (Harley et al., 1998):

$F(\mathrm{PAR})=\frac{\alpha C_{\mathrm{L} 1} \mathrm{PAR}}{\sqrt{1+\alpha^{2} \mathrm{PAR}^{2}}} \times F_{1000}$,

where $\alpha$ and $C_{\mathrm{L} 1}$ are empirical coefficients (Table 2), PAR is the photosynthetically active radiation $\left(\mu \mathrm{mol} \mathrm{m} \mathrm{m}^{-2} \mathrm{~s}^{-1}\right)$ and $F_{1000}$ is the observed flux at $\mathrm{PAR}=1000 \mu \mathrm{mol} \mathrm{m}^{-2} \mathrm{~s}^{-1}$. This relationship was originally developed for emissions of isoprene, which has light-dependent production.

The temperature response flux was divided into lightindependent and light-dependent fractions. The lightindependent fraction (LIDF) of the temperature emission response refers to volatilization processes that do not depend on light but are still temperature dependent, such as the volatilization of pools of organics stored within plant tissues. The flux of the light-independent fraction of temperature responses, $F\left(T_{\mathrm{LIDF}}\right)$, was parameterized according to Eq. (5) (Schade and Goldstein, 2001):

$F\left(T_{\mathrm{LIDF}}\right)=F_{\text {ref }} \times \exp \left(\beta\left(T-T_{\text {ref }}\right)\right)$,

where $\beta$ is an empirical coefficient (Table 3 ), $T$ is the ambient temperature $\left({ }^{\circ} \mathrm{C}\right)$ and $F_{\text {ref }}$ is the observed flux at reference temperature $T_{\text {ref }}=30^{\circ} \mathrm{C}$. For the purposes of comparison, fluxes have been normalized to equal 1 at a temperature of $30^{\circ} \mathrm{C}$ prior to response curve fitting (see Table 3). Temperature responses in the 0 to $30^{\circ} \mathrm{C}$ range follow an exponential function, are fairly similar between individual alkenes and agree well with several other BVOCs, such as methanol, ethanol, acetone, acetaldehyde, monoterpenes and $\alpha$-pinene (Table 3 and Fig. 9).

The light-dependent fraction (LDF) of the temperature emission response refers to the emission of compounds that have recently been produced and emitted without being stored. The flux of the light-dependent fraction of temperature responses, $F\left(T_{\mathrm{LDF}}\right)$, was parameterized according to 


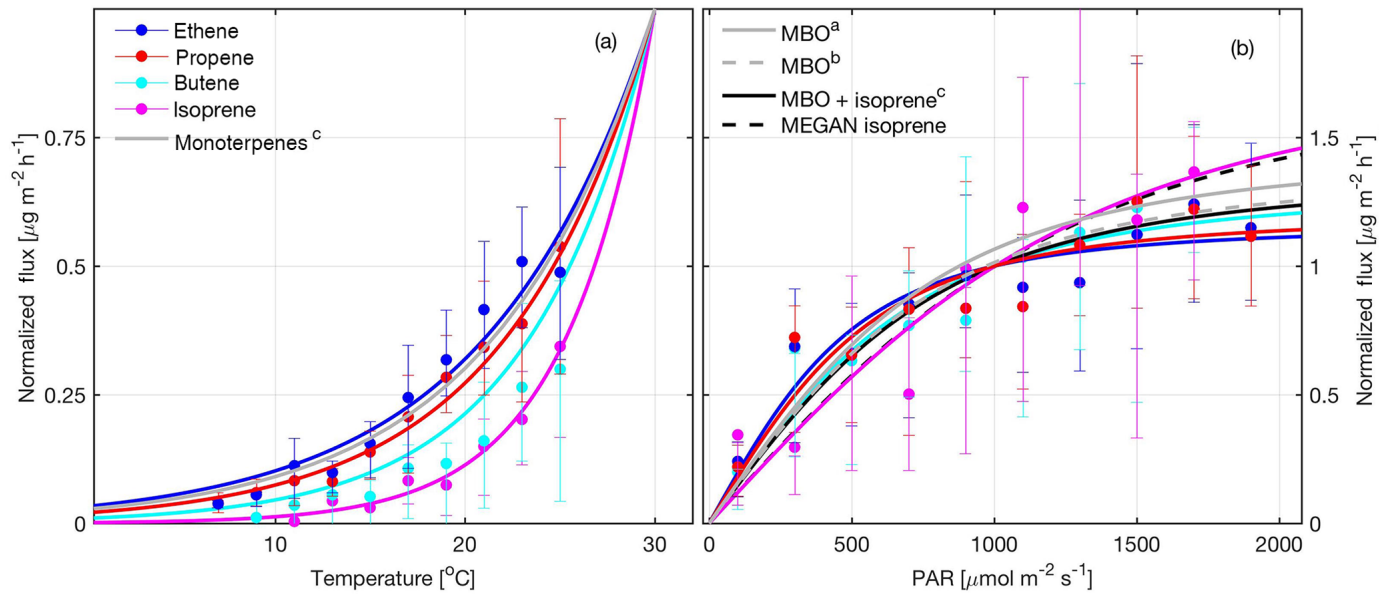

Figure 9. Parameterized response curves (solid lines) of alkene fluxes with 10th-90th percentile (error bars) for (a) the light-independent fraction (LIDF) temperature response (Eq. 5) bin-averaged into $2{ }^{\circ} \mathrm{C}$ classes and (b) the PAR-dependent response (Eq. 4) bin-averaged into $200 \mu \mathrm{mol} \mathrm{m}^{-2} \mathrm{~s}^{-1}$ classes. Response curves are normalized to a flux of 1 at (a) a reference temperature of $30^{\circ} \mathrm{C}$ and (b) a reference PAR of $1000 \mu \mathrm{mol} \mathrm{m}^{-2} \mathrm{~s}^{-1}$. The light-dependent fraction (LDF) temperature response (Eq. 6) curve fit is shown in the Supplement (Fig. S5). The response curves in gray and black are for other BVOCs as cited in Tables 2 and 3: ${ }^{\text {b }}$ Harley et al. (1998); ${ }^{\mathrm{c}}$ Schade and Goldstein (2001); d Kaser et al. (2013a).

Table 3. Fitted coefficients and $r^{2}$ values of temperature response curves for the light-dependent fraction (LDF; Eq. 6) and light-independent fraction (LIDF, Eq. 5) for the light alkenes and isoprene. Literature values for the coefficients of other BVOCs are also shown for comparison. For each compound, the LDF currently used in the MEGAN 2.1 model is also indicated. The $90 \%$ confidence bounds for the fitted coefficients are in the Supplement.

\begin{tabular}{|c|c|c|c|c|c|c|c|c|}
\hline \multirow[b]{2}{*}{ Compound } & \multicolumn{4}{|c|}{$F\left(T_{\mathrm{LDF}}\right)$} & \multicolumn{3}{|c|}{$F\left(T_{\mathrm{LIDF}}\right)$} & \multirow[t]{2}{*}{$\mathrm{LDF}^{\mathrm{e}}$} \\
\hline & $\begin{array}{r}E_{\mathrm{opt}} \\
{\left[\mu \mathrm{g} \mathrm{m}^{-2} \mathrm{~h}^{-1}\right]}\end{array}$ & $C_{\mathrm{T} 1}$ & $C_{\mathrm{T} 2}$ & $r^{2}$ & $\begin{array}{r}F_{\text {ref }} \\
{\left[\mu \mathrm{g} \mathrm{m}^{-2} \mathrm{~h}^{-1}\right]}\end{array}$ & $\beta$ & $r^{2}$ & \\
\hline Ethene $^{\mathrm{a}}$ & 228.0 & 165.2 & 168.0 & 0.98 & 316.0 & 0.114 & 0.93 & 0.8 \\
\hline Propene $^{\mathrm{a}}$ & 410.0 & 116.0 & 148.3 & 0.95 & 326.3 & 0.130 & 0.98 & 0.2 \\
\hline Butene $^{\mathrm{a}}$ & 231.1 & 139.4 & 146.9 & 0.98 & 115.3 & 0.118 & 0.90 & 0.2 \\
\hline Isoprene $^{\mathrm{a}}$ & 193.9 & 136.5 & 154.7 & 0.98 & 367.8 & 0.218 & 0.98 & 1.0 \\
\hline $\mathrm{MBO}^{\mathrm{b}}$ & 2200 & 67 & 209 & & & & & 1 \\
\hline $\mathrm{MBO}^{\mathrm{c}}$ & 2000 & 131 & 154 & & & & & 1 \\
\hline $\mathrm{MBO}+$ isoprene $^{\mathrm{d}}$ & 1800 & 128 & 149 & & & & & 1 \\
\hline Methanol $^{\mathrm{c}}$ & & & & & 7650 & 0.11 & 0.94 & 0.8 \\
\hline Methanol $^{\mathrm{d}}$ & & & & & 940 & 0.13 & 0.81 & 0.8 \\
\hline Ethanol $^{\mathrm{c}}$ & & & & & 1220 & 0.14 & 0.86 & 0.8 \\
\hline Ethanol $^{\mathrm{d}}$ & & & & & 240 & 0.07 & 0.86 & 0.8 \\
\hline Acetone $^{c}$ & & & & & 590 & 0.11 & 0.98 & 0.2 \\
\hline Acetone, propanal ${ }^{\mathrm{d}}$ & & & & & 630 & 0.15 & 0.92 & 0.2 \\
\hline Acetaldehyde ${ }^{c}$ & & & & & 360 & 0.13 & 0.92 & 0.8 \\
\hline Acetaldehyde ${ }^{d}$ & & & & & 330 & 0.12 & 0.85 & 0.8 \\
\hline$\alpha$-Pinene $\mathrm{c}^{\mathrm{c}}$ & & & & & 210 & 0.12 & 0.91 & 0.6 \\
\hline Monoterpenes ${ }^{\mathrm{d}}$ & & & & & 500 & 0.12 & 0.85 & $0.4-0.6$ \\
\hline
\end{tabular}

${ }^{a}$ This study; ${ }^{\mathrm{b}}$ Harley et al. (1998); ${ }^{\mathrm{c}}$ Schade and Goldstein (2001); ${ }^{\mathrm{d}}$ Kaser et al. (2013a); ${ }^{\mathrm{e}}$ Guenther et al. (2012)

Eq. (6) (Schade and Goldstein, 2001; Guenther et al., 2012):

$$
F\left(T_{\mathrm{LDF}}\right)=\frac{E_{\mathrm{opt}} C_{\mathrm{T} 2} e^{C_{\mathrm{T} 1} x}}{C_{\mathrm{T} 2}-C_{\mathrm{T} 1}\left(1-e^{C_{\mathrm{T} 2} x}\right)}, x=\frac{T_{\mathrm{opt}}^{-1}-T^{-1}}{R},
$$

where $C_{\mathrm{T} 1}$ and $C_{\mathrm{T} 2}$ are empirical coefficients, $E_{\mathrm{opt}}$ is the maximum emission capacity at temperature $T_{\mathrm{opt}}$, which was set to $312 \mathrm{~K}$, and $R$ is the universal gas constant (Table 3 ). This relationship is similar to the ones governing MBO emis- 
sions, which are considered to have a light-dependent temperature response curve (Fig. S5).

Emissions show a strong relationship to PAR (Fig. 9), although both temperature response curves showed higher correlation coefficients than the light response curves (Table 2 vs. 3). The curve fits of the temperature emission response using the light-dependent equation (Eq. 6) are slightly better than the fits using the light-independent fraction equation (Eq. 5), suggesting that the alkene emissions have a high light-dependent fraction (LDF). However, the range of temperatures in this study is within the range in which both temperature response curves are similar, thus limiting the assessment of which equation performs better at high temperatures (Figs. 9 and S5).

The similar response curves to other BVOCs further suggest that these alkenes are biogenic in origin and emitted from the canopy during photosynthetically active periods. The MBO flux profile measurements show that MBO emissions are light dependent and increase with height up to $12 \mathrm{~m}$ (Karl et al., 2014; Ortega et al., 2014). Ethene, propene and butene flux responses show an almost linear increase at PAR $<1000$ and asymptotic behavior at $\mathrm{PAR} \approx 2000 \mu \mathrm{mol} \mathrm{m}^{-2} \mathrm{~s}^{-1}$. The isoprene light response, on the other hand, showed less of an asymptote at high PAR. It should be noted that the PAR measurements employed to compute the light response curves were measured above the canopy, while the observed source of isoprene appears to be in the vegetated understory, which experiences more diffuse light. In fact, PAR intensity measured near ground level ( $2 \mathrm{~m}$ a.g.l.) was on average $50 \pm 30 \%$ (standard deviation) of the measured PAR above the forest canopy. Hence, the subcanopy isoprene source(s) may experience an optimum quantum yield at much larger incident PAR (measured above the canopy) than the other alkene source(s) within the ponderosa pine canopy, explaining the different light response curves.

\subsection{Parameterization of fluxes for modeling}

The light alkenes (ethene and propene) are included in the Model of Emissions of Gases and Aerosols from Nature version 2.1 (MEGAN 2.1), which is used to determine the BVOC input into the atmosphere from terrestrial and oceanic ecosystems. Perhaps the best-characterized BVOC in MEGAN 2.1 is isoprene, and it is noteworthy that the modeled parameters for isoprene flux in this study are in excellent agreement with MEGAN 2.1, with nearly identical parameterizations (CL1 $=1.80$ and $\alpha=0.0007$ in this study; $\mathrm{CL} 1=1.74$ and $\alpha=0.0007$ in MEGAN 2.1).

The choice of which temperature-dependent flux response equation to apply varies among different compounds and different studies, as illustrated in Table 3. In our study, both the light-dependent fraction (LDF) and the light-independent fraction (LIDF) equations for temperature response performed better than the PAR response curve. In addition, the PAR response curve goes to zero as PAR goes to zero, although it appears that emissions of ethene, propene and butene still occurred at nighttime when PAR equaled zero. We therefore utilized a combination of the temperature-based equations, scaled by the LDF reported in the MEGAN 2.1 model (last column in Table 3), to extrapolate flux results to the remainder of the season for which flux measurements were not determined. Between 1 May and 31 October 2014, the extrapolated seasonal flux yielded an average of 61.5 , 51.7, 24.3 and $18.0 \mu \mathrm{g} \mathrm{m}^{-2} \mathrm{~h}^{-1}$ for ethene, propene, butene and isoprene, respectively. For the light alkenes, this represents a $40-80 \%$ higher emission rate than that observed over the same season length at Harvard Forest (Goldstein et al., 1996). This is slightly larger than the simple linear extrapolation described in Sect. 5.3 above.

In MEGAN 2.1, ethene is classified as a "stress VOC" owing to its known biochemical production during times of abiotic and biological stress (Abeles et al., 2012), while propene and butene are classified as "other VOCs". In this study, propene and butene fluxes highly correlate with ethene fluxes and show a very similar light and temperature response. Hence, our results suggest that propene and butene can be categorized together with ethene, and their temperaturedependent emissions should have similar LDF values. In MEGAN 2.1, global butene emissions are only $30 \%$ of ethene and $50 \%$ of propene, which is similar to the ratios found here (30 and $40 \%$, respectively). Modifying the light and temperature parameterizations for light alkenes in the vegetation emissions model will lead to a corresponding increase in estimated global emissions for these compounds. This would generally support the conclusion of Goldstein et al. (1996) that "terrestrial biogenic emissions could provide a significant global source for two important reactive olefins, propene and 1-butene", with the caveats that the specific butene isomer remains in question and that other terrestrial ecosystems need to be surveyed.

\section{Conclusions}

The relaxed eddy accumulation technique coupled with GCFID analysis proved to be suitable to quantify fluxes of ethene, propene, butene and isoprene from a coniferous forest canopy. This study demonstrated that coniferous forests can be significant sources of these compounds and that the mass of emissions of the light alkenes alone is roughly $15 \%$ of the dominant emission flux of 2-methyl-3-buten-2ol (MBO) and roughly two-thirds of methanol fluxes. The three light alkenes (ethene, propene and butene) can constitute roughly $12 \%$ of the overall $\mathrm{OH}$ reactivity associated with BVOCs. Thus, the emissions of light alkenes should be included in the overall emissions of reactive organic compounds in the forest atmosphere. Presently, little is known about the flux magnitudes of light alkenes in different ecosystems, e.g., the broadleaf evergreen forests of the tropics. In ecosystems not dominated by MBO or isoprene, light alkenes 
may be major components of the overall BVOC emissions and $\mathrm{OH}$ reactivity. At Manitou Forest, ethene, propene and butene are light and temperature driven and appear to originate from within the canopy. While isoprene emissions are also light and temperature dependent, this compound appears to emanate from near surface vegetation, not the canopy. The strikingly tight correlation between ethene and propene fluxes suggest that they share a mutual mechanism of formation. This is surprising because the biosynthesis of ethene is well established in the literature, while the biological production mechanism of propene is unknown. The correlation of ethene and propene with butene fluxes is another relationship that should be explored, and it remains to be determined if these compounds are produced biologically (i.e., enzymatically) or abiotically (e.g., the breakdown product of organic matter). Due to their reactivity with the hydroxyl, ozone and the nitrate radical, we suggest that these compounds should be incorporated in future BVOC-atmospheric chemistry modeling studies. If the suite of light alkenes are all stress compounds like ethene, their emissions may be enhanced under warmer and/or drier conditions associated with changing climatic conditions.

Data availability. The data used in this study are archived under the year 2014 on the Manitou Experimental Forest Observatory (MEFO) website managed by NCAR at https://doi.org/10.5065/ D61V5CDP (NCAR-ACOM, 2017).

\section{The Supplement related to this article is available online at https://doi.org/10.5194/acp-17-13417-2017- supplement.}

Author contributions. RCR coordinated and executed the MEFO 2014 field campaign; MJD analyzed a majority of the data, applied the flux models and produced the graphs; AT designed, built, deployed and verified the REA system and conducted the understory study; CW upgraded the GC-FID system and provided instrumental support; JO and JS managed MEFO instrumentation and logistics with NCAR; SS and LM conducted the fieldwork; AK, JG and BL helped with GC measurements and calibrations; AG and JdG were co-PIs, supporting modeling, laboratory work, fieldwork and intellectual direction of the project. RCR prepared the paper with contributions from all coauthors.

Competing interests. Alex B. Guenther is a member of the editorial board of the journal. All other authors declare that they have no conflict of interest.

Acknowledgements. We thank the USDA Forest Service and Steve Alton for access, facilities and support at MEFO; Stephen Shertz and Steve Gabbard for research support at NCAR; Alicia Cowart for cartography support (Fig. 1); Allen Goldstein for valuable advice and feedback; Sarah Knox and Cove Sturtevant for support with the ANN model; and Benjamin Miller and Bill Kuster for GC support. Robert C. Rhew thanks CIRES/NOAA and NCAR for their visiting fellows programs. Luis Martinez thanks the NOAA Hollings undergraduate scholarship program. This research project was supported primarily by NSF Atmospheric Chemistry. MEFO is supported by the US Forest Service and NCAR, and NCAR is supported by the NSF.

Edited by: Astrid Kiendler-Scharr

Reviewed by: Jochen Rudolph and one anonymous referee

\section{References}

Abeles, F., Morgan, P., and Saltveit Jr., M.: Ethylene in Plant Biology, 2nd Edn., Academic Press, San Diego, 414 pp., 2012.

Atkinson, R., Aschmann, S. M., and Pitts, J. N.: Rate constants for the gas-phase reactions of the $\mathrm{OH}$ radical with a series of monoterpenes at $294 \pm 1 \mathrm{~K}$, Int. J. Chem. Kinet., 18, 287-299, 1986.

Atkinson, R., Baulch, D. L., Cox, R. A., Hampson, R. F. J., Kerr, J. A., Rossi, M. J., and Troe, J.: Evaluated kinetic, photochemical and heterogeneous data for atmospheric chemistry: Supplement V. - IUPAC Subcommittee on Gas Kinetic Data Evaluation for Atmospheric Chemistry, J. Phys. Chem. Ref. Data, 26, 5211011, https://doi.org/10.1063/1.556011, 1997.

Baker, B., Guenther, A., Greenberg, J., and Fall, R.: Canopy level fluxes of 2-methyl-3-buten-2-ol, acetone, and methanol by a portable relaxed eddy accumulation system, Environ. Sci. Technol., 35, 1701-1708, https://doi.org/10.1021/es001007j, 2001.

Baker, J. M.: Conditional sampling revisited, Agr. Forest Meteorol., 104, 59-65, 2000.

Baker, J. M., Norman, J. M., and Bland, W. L.: Field-scale application of flux measurement by conditional sampling, Agr. Forest Meteorol., 62, 31-52, 1992.

Baldocchi, D., Hicks, B. B., and Meyers, T.: Measuring biosphereatmosphere exchanges of biologically related gases with micrometeorological methods, Ecology, 69, 1331-1340, 1988.

Baulch, D. L., Cobos, C. J., Cox, R. A., Frank, P., Hayman, G., Just, T., Kerr, J. A., Murrells, T., Pilling, M. J., Troe, J., Walker, R. W., and Warnatz, J.: Evaluated kinetic data for combustion modeling supplement I, J. Phys. Chem. Ref. Data, 23, 847-1033, 1994.

Bowling, D. R., Turnipseed, A. A., Delany, A. C., Baldocchi, D. D., Greenberg, J. P., and Monson, R. K.: The use of relaxed eddy accumulation to measure biosphere-atmosphere exchange of isoprene and of her biological trace gases, Oecologia, 116, 306-315, 1998.

Businger, J. A. and Oncley, S. P.: Flux measurement with conditional sampling, J. Atmos. Ocean. Tech., 7, 349-352, 1990.

Chameides, W. L., Fehsenfeld, F., Rodgers, M. O., Cardelino, C., Martinez, J., Parrish, D., Lonneman, W., Lawson, D. R., Rasmussen, R. A., Zimmerman, P., Greenberg, J., Middleton, P., and Wang, T.: Ozone precursor relationships in the ambient atmosphere, J. Geophys. Res., 97, 6037-6055, 1992.

de Gouw, J. A., Hekkert, S. T. L., Mellqvist, J., Warneke, C., Atlas, E. L., Fehsenfeld, F. C., Fried, A., Frost, G. J., Harren, F. J. M., Holloway, J. S., Lefer, B., Lueb, R., Meagher, J. F., Parrish, D. D., Patel, M., Pope, L., Richter, D., Rivera, C., Ryerson, T. B., 
Samuelsson, J., Walega, J., Washenfelder, R. A., Weibring, P., and Zhu, X.: Airborne measurements of ethene from industrial sources using laser photo-acoustic spectroscopy, Environ. Sci. Technol., 43, 2437-2442, https://doi.org/10.1021/es802701a, 2009.

Dengel, S., Zona, D., Sachs, T., Aurela, M., Jammet, M., Parmentier, F. J. W., Oechel, W., and Vesala, T.: Testing the applicability of neural networks as a gap-filling method using $\mathrm{CH}_{4}$ flux data from high latitude wetlands, Biogeosciences, 10, 8185-8200, https://doi.org/10.5194/bg-10-8185-2013, 2013.

Derendorp, L., Holzinger, R., Wishkerman, A., Keppler, F., and Röckmann, T.: Methyl chloride and $\mathrm{C}_{2}-\mathrm{C}_{5}$ hydrocarbon emissions from dry leaf litter and their dependence on temperature, Atmos. Environ., 45, 3112-3119, https://doi.org/10.1016/j.atmosenv.2011.03.016, 2011.

Desjardins, R. L.: Description and evaluation of a sensible heat flux detector, Bound.-Lay. Meteorol., 11, 147-154, 1977.

Di Carlo, P., Brune, W. H., Martinez, M., Harder, H., Lesher, R., Ren, X., Thornberry, T., Carroll, M. A., Young, V., Shepson, P. B., Riemer, D., Apel, E., and Campbell, C.: Missing OH reactivity in a forest: evidence for unknown reactive biogenic VOCs, Science, 304, 722-725, 2004.

DiGangi, J. P., Boyle, E. S., Karl, T., Harley, P., Turnipseed, A., Kim, S., Cantrell, C., Maudlin III, R. L., Zheng, W., Flocke, F., Hall, S. R., Ullmann, K., Nakashima, Y., Paul, J. B., Wolfe, G. M., Desai, A. R., Kajii, Y., Guenther, A., and Keutsch, F. N.: First direct measurements of formaldehyde flux via eddy covariance: implications for missing in-canopy formaldehyde sources, Atmos. Chem. Phys., 11, 10565-10578, https://doi.org/10.5194/acp-11-10565-2011, 2011.

Fantechi, G., Jensen, N. R., Hjorth, J., and Peeters, J.: Determination of the rate constants for the gas-phase reactions of methyl butenol with $\mathrm{OH}$ radicals, ozone, $\mathrm{NO}_{3}$ radicals, and $\mathrm{Cl}$ atoms, Int. J. Chem. Kinet., 30, 589-594, 1998.

Foken, T. and Wichura, B.: Tools for quality assessment of surfacebased flux measurements, Agr. Forest Meteorol., 78, 83-105, https://doi.org/10.1016/0168-1923(95)02248-1, 1996.

Gane, R.: Production of ethylene by some ripening fruits, Nature, 134, 1008, https://doi.org/10.1038/1341008a0, 1934.

Goldan, P. D., Parrish, D. D., Kuster, W. C., Trainer, M., McKeen, S. A., Holloway, J., Jobson, B. T., Sueper, D. T., and Fehsenfeld, F. C.: Airborne measurements of isoprene, CO, and anthropogenic hydrocarbons and their implications, J. Geophys. Res., 105, 9091-9105, 2000.

Goldstein, A. H., Fan, S. M., Goulden, M. L., Munger, J. W., and Wofsy, S. C.: Emissions of ethene, propene, and 1-butene by a midlatitude forest, J. Geophys. Res., 101, 9149-9157, 1996.

Greenberg, J. P., Zimmerman, P. R., Pollock, W. F., Lueb, R. A., and Heidt, L. E.: Diurnal variability of atmospheric methane, nonmethane hydrocarbons, and carbon monoxide at Mauna Loa, J. Geophys. Res.-Atmos., 97, 10395-10413, https://doi.org/10.1029/91JD02295, 1992.

Greenberg, J. P., Asensio, D., Turnipseed, A., Guenther, A. B., Karl, T., and Gochis, D.: Contribution of leaf and needle litter to whole ecosystem BVOC fluxes, Atmos. Environ., 59, 302-311, https://doi.org/10.1016/j.atmosenv.2012.04.038, 2012.

Guenther, A., Baugh, W., Davis, K., Hampton, G., Harley, P., Klinger, L., Vierling, L., Zimmerman, P., Allwine, E., Dilts, S., Lamb, B., Westberg, H., Baldocchi, D., Geron, C., and Pierce, T.:
Isoprene fluxes measured by enclosure, relaxed eddy accumulation, surface layer gradient, mixed layer gradient, and mixed layer mass balance techniques, J. Geophys. Res., 101, 1855518567, 1996.

Guenther, A., Karl, T., Harley, P., Wiedinmyer, C., Palmer, P. I., and Geron, C.: Estimates of global terrestrial isoprene emissions using MEGAN (Model of Emissions of Gases and Aerosols from Nature), Atmos. Chem. Phys., 6, 3181-3210, https://doi.org/10.5194/acp-6-3181-2006, 2006.

Guenther, A. B., Jiang, X., Heald, C. L., Sakulyanontvittaya, T., Duhl, T., Emmons, L. K., and Wang, X.: The Model of Emissions of Gases and Aerosols from Nature version 2.1 (MEGAN2.1): an extended and updated framework for modeling biogenic emissions, Geosci. Model Dev., 5, 1471-1492, https://doi.org/10.5194/gmd-5-1471-2012, 2012.

Haapanala, S., Rinne, J., Pystynen, K.-H., Hellén, H., Hakola, H., and Riutta, T.: Measurements of hydrocarbon emissions from a boreal fen using the REA technique, Biogeosciences, 3, 103112, https://doi.org/10.5194/bg-3-103-2006, 2006.

Hakola, H., Rinne, J., and Laurila, T.: The hydrocarbon emission rates of tea-leafed willow (Salix phylicifolia), silver birch (Betula pendula) and European aspen (Populus tremula), Atmos. Environ., 32, 1825-1833, 1998.

Harley, P., Fridd-Stroud, V., Greenberg, J., Guenther, A., and Vasconcellos, P.: Emission of 2-methyl-3-buten-2-ol by pines: A potentially large natural source of reactive carbon to the atmosphere, J. Geophys. Res.-Atmos., 103, 25479-25486, https://doi.org/10.1029/98jd00820, 1998.

Hellén, H., Hakola, H., Pystynen, K.-H., Rinne, J., and Haapanala, S.: $\mathrm{C}_{2}-\mathrm{C}_{10}$ hydrocarbon emissions from a boreal wetland and forest floor, Biogeosciences, 3, 167-174, https://doi.org/10.5194/bg-3-167-2006, 2006.

Hsieh, C.-I., Katul, G., and Chi, T.: An approximate analytical model for footprint estimation of scalar fluxes in thermally stratified atmospheric flows, Adv. Water Resour., 23, 765-772, https://doi.org/10.1016/S0309-1708(99)00042-1, 2000.

Huang, Y. W., Dransfield, T. J., Miller, J. D., Rojas, R. D., Castillo, X. G., and Anderson, J. G.: Experimental study of the kinetics of the reaction of acetic acid with hydroxyl radicals from 255 to 355 K, J. Phys. Chem. A, 113, 423-430, 2009.

Jarvis, P., Rey, A., Petsikos, C., Wingate, L., Rayment, M., Pereira, J., Banza, J., David, J., Miglietta, F., Borghetti, M., Manca, G., and Valentini, R.: Drying and wetting of Mediterranean soils stimulates decomposition and carbon dioxide emission: the "Birch effect", Tree Physiol., 27, 929-940, 2007.

Karl, T., Kaser, L., and Turnipseed, A.: Eddy covariance measurements of isoprene and 232-MBO based on NO+ time-of-flight mass spectrometry, Int. J. Mass Spectrom., 365-366, 15-19, https://doi.org/10.1016/j.ijms.2013.12.002, 2014.

Kaser, L., Karl, T., Guenther, A., Graus, M., Schnitzhofer, R., Turnipseed, A., Fischer, L., Harley, P., Madronich, M., Gochis, D., Keutsch, F. N., and Hansel, A.: Undisturbed and disturbed above canopy ponderosa pine emissions: PTR-TOF-MS measurements and MEGAN 2.1 model results, Atmos. Chem. Phys., 13, 11935-11947, https://doi.org/10.5194/acp-13-11935-2013, 2013a.

Kaser, L., Karl, T., Schnitzhofer, R., Graus, M., Herdlinger-Blatt, I. S., DiGangi, J. P., Sive, B., Turnipseed, A., Hornbrook, R. S., Zheng, W., Flocke, F. M., Guenther, A., Keutsch, F. N., 
Apel, E., and Hansel, A.: Comparison of different real time VOC measurement techniques in a ponderosa pine forest, Atmos. Chem. Phys., 13, 2893-2906, https://doi.org/10.5194/acp13-2893-2013, $2013 b$.

Katul, G. G., Finkelstein, P. L., Clarke, J. F., and Ellestad, T. G.: An investigation of the conditional sampling method used to estimate fluxes of active, reactive, and passive scalars, J. Appl. Meteorol., 35, 1835-1845, https://doi.org/10.1175/15200450(1996)035<1835:AIOTCS>2.0.CO;2, 1996.

Kim, S., Karl, T., Guenther, A., Tyndall, G., Orlando, J., Harley, P., Rasmussen, R., and Apel, E.: Emissions and ambient distributions of Biogenic Volatile Organic Compounds (BVOC) in a ponderosa pine ecosystem: interpretation of PTR-MS mass spectra, Atmos. Chem. Phys., 10, 1759-1771, https://doi.org/10.5194/acp-10-1759-2010, 2010.

Kuster, W. C., Jobson, B. T., Karl, T., Riemer, D., Apel, E., Goldan, P. D., and Fehsenfeld, F. C.: Intercomparison of volatile organic carbon measurement techniques and data at La Porte during the TexAQS2000 Air Quality Study, Environ. Sci. Technol., 38, 221228, https://doi.org/10.1021/es034710r, 2004.

Launiainen, S., Rinne, J., Pumpanen, J., Kulmala, L., Kolari, P., Keronen, P., Siivola, E., Pohja, T., Hari, P., and Vesala, T.: Eddy covariance measurements of $\mathrm{CO}_{2}$ and sensible and latent heat fluxes during a full year in a boreal pine forest trunk-space, Boreal Environ. Res., 10, 569-588, 2005.

Lin, Z. F., Zhong, S. L., and Grierson, D.: Recent advances in ethylene research, J. Exp. Bot., 60, 3311-3336, 2009.

McCoy, M., Reisch, M. S., Tullo, A. H., Tremblay, J.-F., and Voith, M.: Output declines in U.S., Europe, Chem. Eng. News, 88, 5459, 2010.

Misztal, P. K., Hewitt, C. N., Wildt, J., Blande, J. D., Eller, A. S. D., Fares, S., Gentner, D. R., Gilman, J. B., Graus, M., Greenberg, J., Guenther, A. B., Hansel, A., Harley, P., Huang, M., Jardine, K., Karl, T., Kaser, L., Keutsch, F. N., Kiendler-Scharr, A., Kleist, E., Lerner, B. M., Li, T., Mak, J., Nölscher, A. C., Schnitzhofer, R., Sinha, V., Thornton, B., Warneke, C., Wegener, F., Werner, C., Williams, J., Worton, D. R., Yassaa, N., and Goldstein, A. H.: Atmospheric benzenoid emissions from plants rival those from fossil fuels, Sci. Rep., 5, 12064, https://doi.org/10.1038/srep12064, 2015.

Moffat, A. M., Papale, D., Reichstein, M., Hollinger, D. Y., Richardson, A. D., Barr, A. G., Beckstein, C., Braswell, B. H., Churkina, G., Desai, A. R., Falge, E., Gove, J. H., Heimann, M., Hui, D., Jarvis, A. J., Kattge, J., Noormets, A., and Stauch, V. J.: Comprehensive comparison of gap-filling techniques for eddy covariance net carbon fluxes, Agr. Forest Meteorol., 147, 209-232, https://doi.org/10.1016/j.agrformet.2007.08.011, 2007.

Mogensen, D., Smolander, S., Sogachev, A., Zhou, L., Sinha, V., Guenther, A., Williams, J., Nieminen, T., Kajos, M. K., Rinne, J., Kulmala, M., and Boy, M.: Modelling atmospheric OH-reactivity in a boreal forest ecosystem, Atmos. Chem. Phys., 11, 97099719, https://doi.org/10.5194/acp-11-9709-2011, 2011.

National Center for Atmospheric Research - Atmospheric Chemistry Observations and Modeling (NCAR-ACOM): Manitou Experimental Forest Observatory Field Site, https://doi.org/10.5065/D61V5CDP, 2017.

Nölscher, A. C., Bourtsoukidis, E., Bonn, B., Kesselmeier, J., Lelieveld, J., and Williams, J.: Seasonal measurements of total $\mathrm{OH}$ reactivity emission rates from Norway spruce in 2011,
Biogeosciences, 10, 4241-4257, https://doi.org/10.5194/bg-104241-2013, 2013.

Oncley, S. P., Delany, A. C., Horst, T. W., and Tans, P. P.: Verification of flux measurement using relaxed eddy accumulation, Atmos. Environ., 27, 2417-2426, https://doi.org/10.1016/09601686(93)90409-R, 1993.

Ortega, J., Turnipseed, A., Guenther, A. B., Karl, T. G., Day, D. A., Gochis, D., Huffman, J. A., Prenni, A. J., Levin, E. J. T., Kreidenweis, S. M., DeMott, P. J., Tobo, Y., Patton, E. G., Hodzic, A., Cui, Y. Y., Harley, P. C., Hornbrook, R. S., Apel, E. C., Monson, R. K., Eller, A. S. D., Greenberg, J. P., Barth, M. C., Campuzano-Jost, P., Palm, B. B., Jimenez, J. L., Aiken, A. C., Dubey, M. K., Geron, C., Offenberg, J., Ryan, M. G., Fornwalt, P. J., Pryor, S. C., Keutsch, F. N., DiGangi, J. P., Chan, A. W. H., Goldstein, A. H., Wolfe, G. M., Kim, S., Kaser, L., Schnitzhofer, R., Hansel, A., Cantrell, C. A., Mauldin, R. L., and Smith, J. N.: Overview of the Manitou Experimental Forest Observatory: site description and selected science results from 2008 to 2013, Atmos. Chem. Phys., 14, 6345-6367, https://doi.org/10.5194/acp14-6345-2014, 2014.

Papale, D. and Valentini, A.: A new assessment of European forests carbon exchanges by eddy fluxes and artificial neural network spatialization, Glob. Change Biol., 9, 525-535, 2003.

Papale, D., Reichstein, M., Aubinet, M., Canfora, E., Bernhofer, C., Kutsch, W., Longdoz, B., Rambal, S., Valentini, R., Vesala, T., and Yakir, D.: Towards a standardized processing of Net Ecosystem Exchange measured with eddy covariance technique: algorithms and uncertainty estimation, Biogeosciences, 3, 571-583, https://doi.org/10.5194/bg-3-571-2006, 2006.

Pattey, E., Desjardins, R. L., and Rochette, P.: Accuracy of the relaxed eddy-accumulation technique, evaluated using $\mathrm{CO}_{2}$ flux measurements, Bound.-Lay. Meteorol., 66, 341-355, 1993.

Picquet, B., Heroux, S., Chebbi, A., Doussin, J. F., Durand-Jolibois, R., Monod, A., Loirat, H., and Carlier, P.: Kinetics of the reactions of $\mathrm{OH}$ radicals with some oxygenated volatile organic compounds under simulated atmospheric conditions, Int. J. Chem. Kinet., 30, 839-847, 1998.

Poisson, N., Kanakidou, M., and Crutzen, P. J.: Impact of nonmethane hydrocarbons on tropospheric chemistry and the oxidizing power of the global troposphere: 3-dimensional modelling results, J. Atmos. Chem., 36, 157-230, 2000.

Rannik, Ü., Mammarella, I., Aalto, P., Keronen, P., Vesala, T., and Kulmala, M.: Long-term aerosol particle flux observations part I: Uncertainties and time-average statistics, Atmos. Environ., 43, 3431-3439, https://doi.org/10.1016/j.atmosenv.2009.02.049, 2009.

Ratte, M., Plassdulmer, C., Koppmann, R., Rudolph, J., and Denga, J.: Production mechanism of $\mathrm{C}_{2}-\mathrm{C}_{4}$ hydrocarbons in seawater field measurements and experiments, Glob. Biogeochem. Cy., 7, 369-378, 1993.

Ratte, M., Bujok, O., Spitzy, A., and Rudolph, J.: Photochemical alkene formation in seawater from dissolved organic carbon: results from laboratory experiments, J. Geophys. Res., 103, 57075717, 1998.

Ravishankara, A. R. and Davis, D. D.: Kinetic rate constants for reaction of $\mathrm{OH}$ with methanol, ethanol, and tetrahydrofuran at 298 K, J. Phys. Chem., 82, 2852-2853, 1978. 
Redeker, K. R., Meinardi, S., Blake, D., and Sass, R.: Gaseous emissions from flooded rice paddy agriculture, J. Geophys. Res., 108, 4386, https://doi.org/10.1029/2002JD002814, 2003.

Reid, M. S. and Wu, M. J.: Ethylene and flower senescence, Plant Growth Regul., 11, 37-43, 1992.

Ruppert, J., Thomas, C., and Foken, T.: Scalar similarity for Relaxed Eddy Accumulation methods, Bound.-Lay. Meteorol., 120, 39-63, https://doi.org/10.1007/s10546-005-9043-3, 2006.

Ryerson, T. B., Trainer, M., Angevine, W. M., Brock, C. A., Dissly, R. W., Fehsenfeld, F. C., Frost, G. J., Goldan, P. D., Holloway, J. S., Hubler, G., Jakoubek, R. O., Kuster, W. C., Neuman, J. A., Nicks, D. K., Parrish, D. D., Roberts, J. M., and Sueper, D. T.: Effect of petrochemical industrial emissions of reactive alkenes and $\mathrm{NO}_{x}$ on tropospheric ozone formation in Houston, Texas, J. Geophys. Res., 108, 4249, https://doi.org/10.1029/2002jd003070, 2003.

Sawada, S. and Totsuka, T.: Natural and anthropogenic sources and fate of atmospheric ethylene, Atmos. Environ., 20, 821-832, 1986.

Schade, G. W. and Goldstein, A. H.: Fluxes of oxygenated volatile organic compounds from a ponderosa pine plantation, J. Geophys. Res., 106, 3111-3123, 2001.

Seinfeld, J. H. and Pandis, S. N.: Atmospheric chemistry and physics: from air pollution to climate change, Wiley, New York, 1326 pp., 1998.

Sholl, D. S. and Lively, R. P.: Seven chemical separations to change the world, Nature, 532, 435-437, 2016.

Singh, H. B. and Zimmerman, P. B.: Atmospheric distribution and sources of nonmethane hydrocarbons, in: Gaseous Pollutants: Characterization and Cycling, edited by: Nriagu, J. O., John Wiley \& Sons, New York, USA, 560 pp., 1992.

Turnipseed, A. A., Pressley, S. N., Karl, T., Lamb, B., Nemitz, E., Allwine, E., Cooper, W. A., Shertz, S., and Guenther, A. B.: The use of disjunct eddy sampling methods for the determination of ecosystem level fluxes of trace gases, Atmos. Chem. Phys., 9, 981-994, https://doi.org/10.5194/acp-9-981-2009, 2009.
UNEP: Global Chemicals Outlook - Towards Sound Management of Chemicals, United Nations Environment Programme, 245 pp., 2013.

Wert, B. P., Trainer, M., Fried, A., Ryerson, T. B., Henry, B., Potter, W., Angevine, W. M., Atlas, E., Donnelly, S. G., Fehsenfeld, F. C., Frost, G. J., Goldan, P. D., Hansel, A., Holloway, J. S., Hubler, G., Kuster, W. C., Nicks, D. K., Neuman, J. A., Parrish, D. D., Schauffler, S., Stutz, J., Sueper, D. T., Wiedinmyer, C., and Wisthaler, A.: Signatures of terminal alkene oxidation in airborne formaldehyde measurements during TexAQS 2000, J. Geophys. Res., 108, 4104, https://doi.org/10.1029/2002jd002502, 2003.

Wilson, D. F., Swinnerton, J. W., and Lamontagne, R. A.: Production of carbon monoxide and gaseous hydrocarbons in seawater - relation to dissolved organic carbon, Science, 168, 1577-1579, 1970.

Wyngaard, J. C. and Moeng, C.-H.: Parameterizing turbulent diffusion through the joint probability density, Bound.-Lay. Meteorol., 60, 1-13, 1992.

Xiao, Y., Jacob, D. J., and Turquety, S.: Atmospheric acetylene and its relationship with $\mathrm{CO}$ as an indicator of air mass age, J. Geophys. Res., 112, D12305, https://doi.org/10.1029/2006JD008268, 2007.

Yang, S. F. and Hoffman, N. E.: Ethylene biosynthesis and its regulation in higher plants, Annu. Rev. Plant Phys., 35, 155-189, 1984.

Zimmerman, P. R., Greenberg, J. P., and Westberg, C. E.: Measurements of atmospheric hydrocarbons and biogenic emission fluxes in the Amazon Boundary Layer, J. Geophys. Res., 93, 14071416, 1988. 